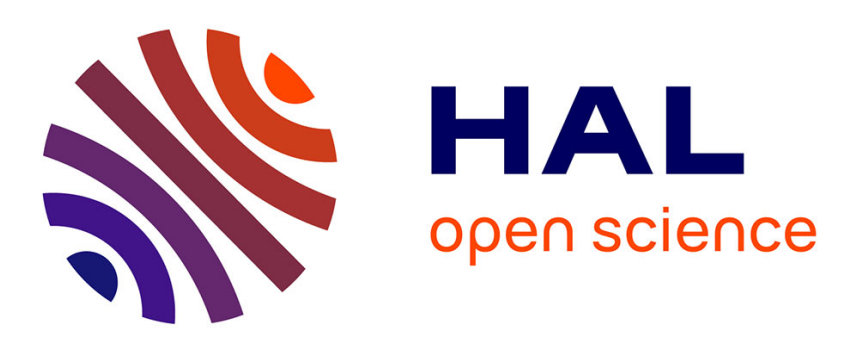

\title{
On the spatial coherence of the Atlantic Water inflow across the Nordic Seas
}

Christophe Herbaut, Marie-Noëlle Houssais, Sally Close, Anne-Cécile Blaizot

\section{To cite this version:}

Christophe Herbaut, Marie-Noëlle Houssais, Sally Close, Anne-Cécile Blaizot. On the spatial coherence of the Atlantic Water inflow across the Nordic Seas. Journal of Geophysical Research. Oceans, 2017, 122 (5), pp.4346-4363. 10.1002/2016JC012566 . hal-01514935

\section{HAL Id: hal-01514935 \\ https://hal.sorbonne-universite.fr/hal-01514935}

Submitted on 26 Apr 2017

HAL is a multi-disciplinary open access archive for the deposit and dissemination of scientific research documents, whether they are published or not. The documents may come from teaching and research institutions in France or abroad, or from public or private research centers.
L'archive ouverte pluridisciplinaire HAL, est destinée au dépôt et à la diffusion de documents scientifiques de niveau recherche, publiés ou non, émanant des établissements d'enseignement et de recherche français ou étrangers, des laboratoires publics ou privés. 
On the spatial coherence of the Atlantic Water inflow across the Nordic Seas.

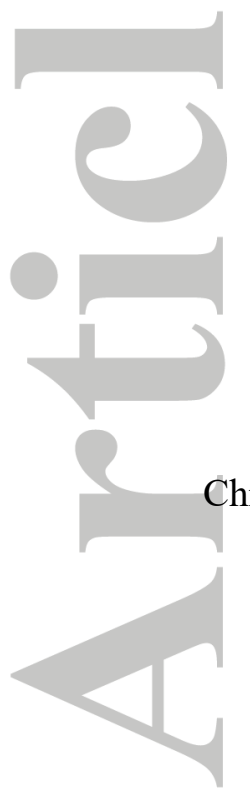

Christophe Herbaut (D), Marie-Noëlle Houssais (D), Sally Close (D) and Anne-Cécile Blaizot.

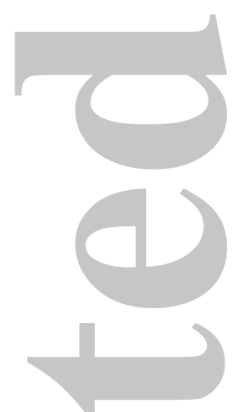

Sorbonne Universités (UPMC Univ. Paris 06)-CNRS-IRD-MNHN, LOCEAN Laboratory, 4 place Jussieu, F-75005 Paris.

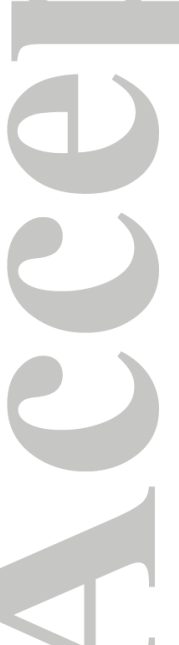

This article has been accepted for publication and undergone full peer review but has not been through the copyediting, typesetting, pagination and proofreading process which may lead to differences between this version and the Version of Record. Please cite this article as doi: 10.1002/2016J C012566

(C) 2017 American Geophysical Union

Received: Nov 18, 2016; Revised: Mar 28, 2017; Accepted: Apr 21, 2017

This article is protected by copyright. All rights reserved. 
Abstract:

The co-variability of the Atlantic Water (AW) branches in the Nordic Seas is investigated over the period 1979-2012 using an eddy permitting model. A noticeable circulation change is found in the mid-1990s. Prior to the mid-1990s, the leading mode of variability defines a large scale pattern, with concomitant variations in the Atlantic Water (AW) inflow in the FaroeShetland Channel (FSC), the Norwegian Atlantic Slope Current (NwASC), the AW inflow to the Barents Sea and the West Spitsbergen Current (WSC). After the mid-1990s, the covariability between the NwASC and the AW inflow in both the FSC and the WSC is lost. Consequently, the northern Barents Sea circulation anomaly pattern, which is present throughout the full period, becomes the leading mode of circulation in the northern Nordic Seas after the mid-1990s. The circulation change of the mid-1990s appears to be linked to a weakening of the southwesterly wind anomalies in Norwegian Sea, as the northern center of action of the first mode of sea level pressure (NAO) weakens. Passive tracer experiments suggest that this circulation change may be accompanied by increased heat transfer from the AW current to the interior Nordic Seas. This in turn may have limited the influence of the recently observed AW warming in the Iceland-Scotland Passage on the NwASC downstream. 


\section{Introduction.}

The recent decline in the Arctic sea ice cover has motivated an increased interest in the effect of Atlantic water (AW) on sea ice variability. For example, in the Barents Sea, the expansion/retreat of the sea ice edge has been linked with AW temperature anomalies or variations in the AW heat inflow through the Barents Sea Opening (BSO) (Schlichtholz, 2011; Årthun et al., 2012; Sandø et al., 2014, Onarheim et al., 2015). In the Kara Sea, patterns of low sea ice thickness coincide with the path of the Atlantic Water in St Anna Trough (Dmitrenko et al., 2014). On the western shelf of Svalbard, winter sea ice melting is observed in regions of Atlantic water subduction (Tverberg et al., 2014). The processes which were identified as influential to the AW inflow include reemergence of temperature anomalies formed in the previous winter in the Barents Sea (Nakanowatari 2014; Herbaut et al., 2015), enhanced vertical mixing in the Nansen Basin ice margin (Dmitrenko et al., 2014), cross shelf exchanges caused by eddy activity (Tverberg et al., 2014; a detailed discussion of these processes can be found in Carmack et al., 2015).

The recent AW warming event in the Arctic Ocean (Polyakov et al., 2010; Karcher et al., 2011) may have enhanced the potential role of the AW in driving sea ice changes. This warming was also observed in the Nordic Seas, where four such events, each lasting 3-4 years, have occurred since the 1950s (Carton et al., 2011; Skagseth et al., 2008; Walczowski and Piechura, 2007). While the most recent event was attributed to an increase of the temperature of the AW inflow due to changes in the subpolar gyre circulation (Häkkinen et al. 2011a), some events were rather argued to be the result of an increase of the volume inflow through the Greenland Scotland Ridge (GSR) and an intensification of the AW circulation in the Nordic Seas (Karcher et al., 2003). 
The AW circulation in the Nordic Seas, fed by the inflow across the GSR, is formed of two main branches (Figure 1), the Iceland Faroe Ridge (IFR) and Faroe Shetland Channel (FSC) inflows, and a third smaller branch to the west of Iceland (Østerhus et al., 2005). Over the IFR, the AW is thought to be pulled into the Norwegian Sea due to the lower sea surface height (SSH) in the southern Norwegian Sea (Hansen et al., 2010; Richter et al, 2012), which may be caused by the overflow of dense water into the North Atlantic (Hansen et al., 2010). In the $\mathrm{FSC}$, however, the wind stress is a major driver for the variability of the $\mathrm{AW}$ inflow at the seasonal scale (Sherwin et al., 2008), while atmospheric cyclones have also been suggested to influence the transports at the interannual time scales (Richter al., 2009). However, the mechanisms by which the wind exerts a control on the AW inflow are not yet fully understood. The wind stress curl in the North Atlantic may play a role in driving changes in the baroclinic transport through the channel by forcing mixed layer depth anomalies south of the sill (Sandø and Furevik, 2008). The local wind in the channel can also affect the depth of the interface between the AW and the dense water layers (Sandø et al., 2012), leading to correlation between the AW inflow and the dense overflow (Serra et al., 2010, Sandø et al., 2012).

Downstream of the GSR, the AW flows poleward along the Norwegian coast as the Norwegian Atlantic Current (NwAC). The latter comprises two veins (Orvik and Niiler, 2002): the Norwegian Atlantic Slope Current (NwASC), which follows the Norwegian continental shelf edge (Andersson et al., 2011), and an off-shore branch, the Norwegian Atlantic Front Current (NwAFC), coinciding with the polar front. In the vicinity of the BSO, the NwASC separates into two branches: one veers eastwards into the Barents Sea, while the other flows northward to form the West Spitzbergen Current (WSC). The along-shore component of the wind exerts a strong control on the variability of the NwAC, on short (shorter than 6 months, Skagseth, 2004) as well as longer (interannual) timescales (Richter 
and Mauss, 2011), by driving accumulation of water along the western coast of Norway. Farther downstream, in BSO, the same mechanism, building on the divergence associated with the meridional component of the Ekman transport, has been suggested to control the sea surface height gradient normal to the northern coast of Norway at intraseasonal timescales, and, consequently, the inflow to the Barents Sea (Ingvaldsen et al., 2004). At interannual timescales, southwesterly winds that promote enhanced net volume transport through BSO have also been shown to be associated with an extended cyclonic pattern over the central Nordic Seas (Karcher et al., 2003).

Previous analyses of the coherence of the transports in the different AW veins across the Nordic Seas have shed light onto the dynamics of the AW inflow to the Arctic. While the NwASC could be viewed as the continuation of the AW inflow that passes through the FSC, the AW transports in the NwASC and the FSC are only weakly correlated over the period 1995-2004 (Richter al., 2009). In contrast, some (moderate) simultaneous correlation (0.41) was found between the monthly transports through BSO and through the Svinoy section (Skagseth et al., 2008). The robustness of these links may, however, be questioned, as they are based on short time series, especially when velocity measurements are concerned (the latter being available only since the mid-1990s). This is of particular concern considering that the mid-1990s emerge as a crucial time period with regards to several indices of ocean variability. This period marks the beginning of a positive trend in the temperature and salinity of the AW inflow (Larsen et al., 2012; Hansen et al, 2015), which was attributed to advection of warmer and saltier water from the subtropical gyre (Häkkinen et al., 2011a), while, at the same time, the subpolar gyre underwent a deceleration and retracted westward (Häkkinen and Rhines, 2004; Hàtun et al., 2005). The subpolar gyre's decline was linked to decadal buoyancy forcing variations, associated with the North Atlantic Oscillation (Häkkinen and Rhines, 2004) but changes in the wind stress curl as a result of the abrupt NAO shift in 1995 were also 
suggested as possible drivers of the increase in the heat and salt content in the eastern part of the gyre (Barrier et al., 2015; Thierry et al., 2008; Herbaut and Houssais, 2009).

The NAO, the dominant mode of atmospheric variability in the North Atlantic region (Wallace and Gutzler, 1981), acts over a large range (from intraseasonal to multidecadal) of timescales (Hurrell and Deser, 2009; Woollings et al., 2015). In particular, after a strong positive trend in the index from the mid-1960s to the mid-1990s, culminating in persistently large positive values in the early 1990s (Hurrell, 1995), a negative trend was observed (Pinto and Raible, 2012). Changes in the spatial pattern of the NAO were also observed over recent decades, in particular a northeastward shift of the northern center of action (Zhang et al., 2008), which could be linked to the decreasing frequency of occurrence of the Greenland Blocking regime (Davini et al., 2012).

Motivated by the above atmospheric circulation shifts and the shortness of the ocean observation record, our aim in this study is to evaluate the robustness of the relationship between the different branches of the AW circulation in the Nordic Seas, as identified in recent years, and to examine how closely this relationship relates to the evolution of the atmospheric forcing patterns. We use a simulation performed with a regional ocean-sea ice model covering the period 1979-2012, providing a longer time span than the observational record. The analysis is performed at selected sections corresponding to sites of field observations along the AW pathway. It focuses on the winter period (hereafter defined as an average of the January, February and March months, if not otherwise specified) when the effect of the wind forcing is expected to be the strongest.

The paper is organized as follows: the model simulation and its ability to reproduce the observed variability in the AW circulation are presented in Section 2. Simulation results are presented in Section 3 and discussed in Section 4. A summary is provided in Section 5. 


\section{Model set-up and validation of the main AW flow structure.}

The sea ice-ocean model is based on NEMO (Nucleus for European Modelling of the Ocean) version 3.2 (Madec, 2008) ocean model coupled to the LIM2 (Fichefet and Morales Maqueda, 1997) sea ice model. The equations are discretized on 46 vertical levels with thickness varying from $6 \mathrm{~m}$ in the top layer to roughly $250 \mathrm{~m}$ at the deepest model level. Partial steps are used to improve the representation of the bottom topography. The domain encompasses the Arctic Ocean and the Atlantic Ocean, with open boundaries at $30^{\circ} \mathrm{S}$ in the Atlantic and $50^{\circ} \mathrm{N}$ in the Pacific, along which the velocity and tracer distributions are prescribed from the monthly climatology of a global simulation. The model grid has a horizontal resolution varying from $10 \mathrm{~km}$ in the Arctic Ocean to $25 \mathrm{~km}$ at the equator.

The model is initialized from rest with initial temperature and salinity distributions from the PHC 3.0 global ocean climatology, updated from Steele et al. (2001). The model surface forcing is based on daily surface atmospheric fields from the ERA-I reanalysis (Dee et al., 2011). Regional corrections have been made to improve the radiation fluxes over the North Atlantic and the surface air temperature over the Arctic. All corrections have been applied to the annual climatological cycle, while the field anomalies (obtained by subtracting this climatology from the original daily fields) have been kept unchanged. Over the Atlantic Ocean, the ISCCP radiation climatology (Rossow and Schiffer, 1999) is used instead of ERAI while in the Arctic Ocean (north of Fram Strait) the ERA-I air temperature climatology is replaced by the IABP climatology (Rigor et al. 2000) The river runoff is prescribed from the monthly climatology proposed in the AOMIP protocol (http://www.whoi.edu/projects/aomip). The salinity in the top model layer is restored to the PHC climatology with a time scale of 30 days. More details about the forcing and the simulation analysed in the present study can be

found in Herbaut et al. (2015). The 34-year simulation used for the present analysis was found to successfully reproduce the essentials of the AW circulation and properties in the Barents 
Sea (Herbaut et al., 2015). We also performed two additional experiments including the release of passive tracers as two distinct, constant sources in the IFR and FSC, respectively. In order to contrast the circulation prior to and after the major NAO shift in the mid-1990s, one simulation was initialized in 1979 and integrated up to 1995, while the other was initialized in 1996 and run over the period 1996-2012.

The mean circulation in the Nordic Seas simulated by the model (Figure 2) over the period 1979-2012 is in qualitative agreement with observations. In the Faroe Shetland Channel (FSC), part of the Faroe Current recirculates southward and merges with the Atlantic inflow, as previously described by Larsen et al. (2012). This inflow is fed by the slope current (SC) flowing along the European continental slope and the northeastward flow along the southern slope of the Faroe Islands, consistent with the observations of Rossby et al. (2009) and Berx et al. (2013). On average, over the 1993-2012 period (the period common to the model simulation and observations), the sum of the two AW inflows through the IFR (as measured on a control section north of the Faroe Islands) and the FSC is $\sim 6.1 \mathrm{~Sv}$ in the model. This is in agreement with observational estimates, even if the distribution between the two passages differs from the observations: in the FSC the simulated mean transport $(\sim 4.6 \mathrm{~Sv})$ is greater than the recent estimates of $2.7 \pm 0.5 \mathrm{~Sv}$ by Berx et al. (2013), while the simulated transport through IFR is underestimated by 1-2 Sv compared to the estimates of $3.5 \pm 0.5$ and $4.6 \pm 0.5$ Sv deduced from observations by Hansen et al. (2010) and Childers et al. (2014), respectively. In the FSC, the simulated transports have been compared to observations based on altimeter data and current measurements (available at http://www.naclim.eu, Berx et al.,2013). The monthly (annual) observed and simulated transports correlate at $0.64(0.65)$ (all correlations given in the text are significant at the 95\% level) over the period 1993-2012 (monthly transports are not deseasoned). 
Farther north, in the Norwegian Sea, the model adequately simulates the two branches of the NwAC, with the core of the NwASC located over the slope (Figure 3a), as reported by Orvik and Skagseth (2005), and a more baroclinic, slower western branch (the NwAFC) in agreement with observations by Høydalsvik et al. (2013). Over the period during which observations are available (1995-2004), the simulated annual mean velocity of the NwASC is somewhat lower than in the observations (core velocities on the order of $20 \mathrm{~cm} / \mathrm{s}$ instead of 30 $\mathrm{cm} / \mathrm{s}$ ). Using monthly (not deseasoned) values, the cross-slope gradient of $\mathrm{SSH}$ over the continental slope, which successfully describes the variations of the transport in the NwASC (Chafik et al., 2015), is found to correlate significantly $(\mathrm{r}=0.75)$ with the observations derived from altimetric products (produced by Aviso with support from CNES, see http://www.aviso.altimetry) over the period 1993-2012. The correlation is still high (0.63) when winter values are used. The simulated winter temperatures in the NwAC at the Svinoy section have also been compared with the observations from the World Ocean Database (Seidov et al., 2014) for the pre and post mid-1990s periods. Prior to 1990, sufficient data are not available to recreate the section for any given winter; the temperature field over the first period has therefore been reconstructed using a least-squares optimal interpolation method employing observations from 1990 to 1996. In contrast, sufficient data are available to reconstruct the post mid-1990s period. The temperature pattern is reasonably simulated by the model, even if the core of the AW is narrower and extends more deeply in the model (Figure 4a-d). The temperature gradients are more diffuse in the model which should lead to underestimated velocities in the NwAFC. Lastly, the post mid-1990s warming of the AW is also well reproduced.

The simulated inflow through the Barents Sea Opening (BSO) has three main branches: the Norwegian Coastal Current (NCC) on the shelf, and two offshore AW branches, one over the continental slope, and the other in Bear Island Trough (Figure 3b). Part of the latter 
recirculates westward and exits the opening as a current flowing westward in the northern part of Bear Island Trough. This scheme is in qualitative agreement with observations (Skagseth, 2008; Skagseth et al. 2011). Over the period 1979-2012, the simulated mean inflow through BSO (including the NCC) amounts to $\sim 4.2 \mathrm{~Sv}$, while the outflow reaches $\sim 1 \mathrm{~Sv}$. The inflow reduces to $2.4 \mathrm{~Sv}$ if only the Atlantic Water (defined as water with salinity greater than 35 ) is considered. The AW inflow and outflow transports are close to the estimates of $2 \mathrm{~Sv}$ by Skagseth et al. (2008) and 0.9 Sv by Skagseth (2008), respectively. Finally, the variability of the temperature at $\mathrm{BSO}$ is also well represented with the highest correlations between the model and the observations found in winter and spring $(\mathrm{r}>0.8)$.

At $75^{\circ} \mathrm{N}$, the AW current is clearly identified in the winter-averaged normal component of velocity (hereafter referred to as the normal velocity) on a section along $75^{\circ} \mathrm{N}$ (Figure $3 \mathrm{c}$ ).

The core of the current lies over the $1000 \mathrm{~m}$ isobath, as observed in summer observations (Walczowski, 2013), while farther offshore a less intense and more baroclinic branch is linked with the Polar Front, as described by Walczowski and Piechura (2007). As for the Svinoy section, the temperature along a section at ca. $75^{\circ} \mathrm{N}$ has been reconstructed from the observations and compared with the field simulated by the model (Figure 4d-h). The simulated and observed fields are in reasonable agreement, even if the AW core is larger and warmer by $0.5^{\circ} \mathrm{C}$ in the model, with more diffuse surrounding gradients.

To obtain a broad estimate of the model interannual variability at larger spatial scales, EOFs of the mean winter SSH anomalies in the Nordic Seas have been compared with those derived from altimetric products starting from the beginning of the observation period (1995-2012). The first loading patterns are similar (not shown), and the corresponding principal components $(\mathrm{PC})$ are well correlated $(\mathrm{r}=0.72)$. The similarity is not as good on a more regional scale, for instance in the Barents Sea where smaller scale features of the altimetric products are not always present in the simulated SSH. Yet, for each individual winter month, 
the first two PCs of the simulated and observed SSH in the Barents Sea are well correlated (r $>0.75)$. An even higher correlation $(r=0.9)$ is found between the leading mode of the simulated and the observed SSH along the section north of the Faroe Islands (which capture most of the IFR inflow (Hansen et al., 2015)). The model loading pattern, however, displays a weaker slope across the section, suggesting that the variability of the surface velocity in the Faroe Current is weaker in the model than in the observations.

\section{Results}

\section{III.1 Evidence of circulation changes in the mid-1990s.}

Along the Svinoy section, in the southern Norwegian Sea, year-to-year fluctuations of the winter-averaged volume transport associated with the core (defined as velocities larger than 8 $\mathrm{cm} \mathrm{s}^{-1}$ ) of the NwASC current show a change in amplitude in the mid-1990s (Figure 5, red line). Separating the time series into two sub-periods, 1979-1996 and 1997-2012, and applying an F-test, the change in variance between the two sub-periods is indeed significant. Similarly, a significant change in variance is detected in the core of the AW current farther north, at $75^{\circ} \mathrm{N}$, although this is less visually obvious (Figure 5, blue line). Perhaps the most interesting feature is the change in covariability between the transports through the Svinoy section and through the $75^{\circ} \mathrm{N}$ section from the mid-1990s onward. The correlation between the two transports is high prior to $1997(\mathrm{r}=0.95)$ but is not significant over the following 1997-2012 sub-period, suggesting a change in the AW circulation around 1996.

In order to characterize the dominant modes of cross-flow variability in the AW current in the Nordic Seas, an EOF analysis of the normal velocity through key sections crossing the AW pathway was performed. At the Svinoy section, the variability of the current prior to 1997 is primarily concentrated in the slope current (Figure 6a). This first mode, which represents 47\% of the total variance, explains more than $80 \%$ of the variance of the NwASC volume 
transport. In the following period, the variability of the NwASC no longer dominates the variations of the NwAC: the first loading pattern rather captures the variability of the offshore branch of the current (Figure 6b), while the variability of the NwASC transport is mainly (roughly $60 \%$ of the transport variance) explained by the third mode (which represents $15 \%$ of the total variance). Farther north, at $75^{\circ} \mathrm{N}$, prior to 1997 , the variations in the core of the slope current represent the dominant loading pattern retrieved from an EOF analysis (Figure 6c). After the mid-1990s, the variance in the core of the current is significantly reduced, and the dominant loading pattern (Figure 6d) mainly reproduces the variations of the inshore boundary of the current.

Prior to the mid-1990s, the regression of the current velocity at $130 \mathrm{~m}$ (in the core of the AW layer) onto the PC associated with the dominant mode of current variability at the Svinoy section at zero lag (Figure 6a) displays a large scale pattern of circulation anomalies. The pattern extends from the AW inflow region in the FSC across the NwASC and into BSO (Figure 7a). This PC is strongly correlated with the PC associated with the dominant mode of current variability at $75^{\circ} \mathrm{N}(\mathrm{r}=0.88)$ and also with the AW inflows both in the FSC $(\mathrm{r}=0.75)$ and through BSO $(r=0.67)$. These high correlations confirm that the large scale pattern shown in Figure 7 a characterizes the dominant mode of variability prior to 1997. At the Svinoy section, this mode is associated with southwesterly wind anomalies along the western Norwegian coast, turning to westerly anomalies over the North Sea (Figure $7 b$ ) and wind curl anomalies extending across the Nordic Seas with a maximum over the Iceland-Faroe Ridge (Figure 7c). (Note that, while simultaneous correlations with these atmospheric variables are high, the maximum correlations are found with the wind preceding the ocean by one month, i.e. averaged over December to February). The patterns in Figures $7 \mathrm{~b}$ and $\mathrm{c}$ are in agreement with conclusions of earlier studies suggesting that the wind stress curl over the GSR could impact the AW inflow in the FSC (Sandø et al., 2014) while intensification of the NwASC 
along the Norwegian coast would respond to enhanced southwesterly winds (e.g., Skagseth, 2004; Richter et al., 2009).

After the mid-1990s, the first mode of variability of the NwAC in the southern Norwegian Sea is mainly located in the NwAFC (Figure 6b) and is no longer wind-driven (no significant pattern emerges from the regression of the wind onto the first PC of the normal velocity along the Svinoy section). This mode is associated with eddies and recirculation in the southern Norwegian Sea (Figure 8), and does not show significant correlation with the volume transport in the NwASC. The correlation of the latter with the AW inflow either upstream in the FSC or downstream at $75^{\circ} \mathrm{N}$ is no longer significant, suggesting a local mode of circulation confined to the Norwegian Sea.

Beyond the $\mathrm{BSO}$, at $75^{\circ} \mathrm{N}$, part of the variability of the AW flow arises as a result of the displacement of the inshore boundary of the current (Figure 6c and d). Over the period 19792012 (or over either of the two sub-periods) the variations of the transport in the inshore region (which is where the velocity standard deviation exceeds $4 \mathrm{~cm} / \mathrm{s}$ ) do not show any significant correlation with the variations farther offshore in the core of the current. This suggests two distinct drivers for these two modes of variability of the current at this latitude. The regression of the $10 \mathrm{~m}$ wind onto the inshore transport indeed reveals that enhanced northward transport is associated with an anticyclonic wind pattern (Figure 9b) and significant negative wind curl anomalies centered over the western Barents Sea (Figure 9c). This wind pattern is clearly distinct from the pattern associated with the variations in the core of the AW slope current (not shown), which resembles the pattern associated with the NwASC variations at the Svinoy section (Figure $7 \mathrm{~b}$ ). The wind anomalies in Figure $9 \mathrm{~b}$ enhance altogether the outflow in the north of BSO (i.e the recirculation branch of AW in the Bear Island Trough) and the northward flow at the inshore boundary of the AW current farther north (Figure 9a). The forcing mechanism of this ocean mode and the associated circulation anomaly pattern 
around the northern Barents Sea shelf are consistent with those proposed by Lien et al. (2013) and Chafik et al. (2015). While this local mode of variability is identified over the full period,

it is only after 1996, when the large-scale mode of circulation linking the variability of the NwASC to that beyond BSO is declining, that it emerges as the major mode of ocean circulation variability in the northern Nordic Seas.

\section{III.2 Origin of the changes in the AW circulation.}

Several studies have suggested that the along shore component of the wind off Norway plays an important role in driving the variability of the NwASC. This causal link is indeed confirmed by our regression analysis (Figure $7 b$ ). In order to analyse this link further, an index was therefore constructed based on the component of the wind parallel to the Norwegian coast (i.e., the southwesterly component), averaged over the domain shown as a red box in Figure 7b. As for the NwASC, this index undergoes a change in the mid-1990s, which is marked by a significant decrease in variance (Figure 10). A change in frequency is also detected in the time series of the index, as is observed in the transport of the NwASC

(Figure 5). This change in the alongshore component of the wind could have contributed to the change in the variability of the NwASC transport.

Computing the surface wind associated with the first PC of the December-February sea level pressure (SLP) over the domain $90^{\circ} \mathrm{W}-40^{\circ} \mathrm{E} ; 20-80^{\circ} \mathrm{N}$ (an equivalent to the NAO index), separately over the two sub-periods, yields somewhat different patterns. Prior to 1997, southwesterly winds anomalies of larger amplitude, which are linked with a deeper low pressure anomaly over the Nordic Seas and a strengthening of the SLP gradient over the Norwegian Sea (Figure 11a), occur along the Norwegian coast while, during the second sub-

period, the amplitude of the wind anomalies in the southern Norwegian Sea is reduced after the low pressure center has weakened, leading to weaker SLP gradients over the Norwegian 
Sea (Figure 11b). The contrast suggests that the decrease of the southwesterly component of the wind along the Norwegian coast in the mid-1990s can be related to a concomitant change in the wind pattern associated with the primary mode of atmospheric variability.

Prior to the mid-1990s, strong southwesterly/northeasterly wind anomalies along the Norwegian coast drive large fluctuations in the along-slope component of the NwASC, which are manifest farther downstream in the AW inflow through BSO and in the AW flow at $75^{\circ} \mathrm{N}$. The resemblance between the wind pattern associated with the AW transport at $75^{\circ} \mathrm{N}$ (not shown) and that associated with the transport of the NwASC at Svinoy (Figure 7b), together with the absence of significant wind anomalies in this pattern north of $70^{\circ} \mathrm{N}$, are consistent with the AW flow at $75^{\circ} \mathrm{N}$ being mainly remotely forced from the NwASC. In contrast, after 1996, in response to the decrease in amplitude of the southwesterly wind anomalies off the Norwegian coast (Figure 10), the velocity anomalies in the NwASC are reduced and no longer dominate the current variability through the Svinoy section. As a consequence, their impact on the variability of the current farther north decreases. The current variations beyond the $\mathrm{BSO}$ are then more sensitive to changes in the AW recirculation in the northern BSO and, therefore, to the wind stress curl anomalies developing over the northern Barents Sea.

Prior to the mid-1990s, the strong southwesterly wind anomalies along the Norwegian coast (Figure 10) coincide with the predominance of a large scale surface wind curl anomaly extending over the GSR (Figure 11c). The simultaneous occurrence of these two features explains why the variability of the NwASC at the Svinoy section is correlated at 0.75 with the variability of the AW inflow in the FSC. In contrast, from 1997 onwards, weaker wind curl anomalies over the GSR (Figure 11d) may explain the decorrelation between the NwASC and the AW inflow in the FSC. Similar decorrelation was also found by Richter et al. (2009) using monthly transports derived from observations over a slightly shorter period (1995-2005). 
The variations in the transport of the NwASC at Svinoy are in phase with those in the outflow of the Norwegian Trench in the northeastern North Sea throughout the full period (Figure 5) which is consistent with the continuous flow pattern found along the southwestern Norwegian coast in Figure 7a. This covariability can be explained by the predominance of westerly wind anomalies, over the North Sea throughout the full period (Figure 11a and b), which have been shown to be an important driver of the variations of the Norwegian Trench outflow, at least at the monthly time scale (Winther et al., 2006). The regression pattern in Figures $7 \mathrm{~b}$ and 12a confirms that these westerly wind anomalies are concomitant to the southwesterly anomalies driving the AW transport at Sivnoy, adding extra forcing on this transport via the Norwegian Trench outflow.

\section{Discussion.}

The analysis of an ocean model simulation forced by ERA-Interim atmospheric surface fields over the period 1979-2012 suggests that the variability of the NwAC in the Nordic Seas undergoes a substantial change around the mid-1990s and that this circulation shift is closely linked to a change in the large scale distribution and variance of the wind field in the Norwegian Sea - GSR region which occurs after 1996. The most drastic change occurs in the NwASC, and manifests in the loss of the large scale spatial coherence (joining the FSC to the $\mathrm{BSO}$ and western Bear Island slope) of the current variability across the Norwegian Sea observed prior to 1997, and the emergence of distinct, more local modes of variability both in the southern Norwegian Sea and in the region to the north of BSO after this time. While lack of a strong correlation between the NwASC and the WSC over the period 1993-2012 has already been stressed by Chafik et al. (2015) based on the observed ocean SSH distribution, our analysis provides a longer term perspective in contrasting this recent period with the earlier, pre-1997 period. Additionally, while both our analysis and that of Chafik et al. suggest that the variability of the AW current north of BSO is linked to a regional mode of circulation 
along the western slope of the Bear Island-Spitsbergen Bank, the present model simulation highlights the robustness of this link throughout the period 1979-2012, based on the distribution of current anomalies.

The large-scale change in circulation around the mid-1990s is also associated with a decrease in the variance of the NwASC transport, which is concomitant with a decrease in the variance of the along-slope component of the surface wind, the primary forcing of the current according to several earlier studies (Skagseth, 2004; Richter and Mauss, 2011). While enhanced atmospheric variability prior to the mid-1990s has already been suggested by Richter et al. (2012) to be potentially responsible for stronger interannual fluctuations of the NwASC during that period, the present analysis provides a quantitative evaluation of the link sustaining such an hypothesis.

In order to put the present analysis into a wider context, the wind index constructed from the along-slope component of the surface wind off the Norwegian coast can be extended backward to 1948 using the NCEP dataset (Figure 10). A visual analysis suggests that the period of greater wind variance previously diagnosed from the ERA-I dataset started as early as 1967. This period is dominated by lower frequency variability than the rest of the time series, with four events of 3 to 5 year duration. Furthermore, as for the period 1997-2012, the variability of the index over the period prior to 1967 is characterized by comparatively higher frequency and lower variance, suggesting that the mode of circulation variability which has been predominant since the mid-1990s, was also at work over the period 1948-1966.

Our simulation results suggest a leading role of the large-scale surface wind stress distribution over the Norwegian Sea in controlling the interannual variability of the NwASC, though in distinct ways depending on the time period. Prior to 1996, the first EOF of the winter North Atlantic SLP (Figure 11a) defines an atmospheric pattern very similar to that identified by 
Skagseth et al. (2008) in relation to anomalously high AW transport events in the NwASC and the BSO inflow. The similarity confirms that the dominant mode of atmospheric variability during that period may have had a strong impact on both the NwASC and the AW inflow through BSO. In contrast, the direction of the wind fluctuations linked to the NwASC over the second sub-period shifts from southwesterly to westerly (Figures $7 b$ and $12 a$ ), and the link between the NwASC and the southwesterly wind weakens over the Norwegian Sea (the correlation between the AW transport through the Svinoy section and the southwesterly wind index decreases from 0.78 over the first sub-period to 0.51 over the second sub-period). Over the second sub-period, the NwASC is mainly influenced by the branch of the AW flow which recirculates in the northern North Sea. The AW inflow to the North Sea is indeed linked with westerly wind anomalies (Winther et al., 2006), and is associated with both an outflow of fresh water which feeds the NCC and an outflow of AW which feeds the NwASC in the upper slope region. This may explain the shift (in the mid-1990s) toward a more westward direction of wind anomalies which preferentially influence the NwASC. Note that the SLP composite of Skagseth et al. (2008) was in fact calculated on part of this second period, suggesting that during this period when the year-to-year variability is clearly associated with a different forcing pattern relative to the first period, there are particular years when the winds are aligned with the along-slope direction and favor fluctuations in the NwASC transport in a way similar to that observed in the first period.

While the above results and those of earlier studies consistently suggest that the strong link between the variability of the NwASC and that of the wind is linked to coastal SSH anomalies driven by along-Norwegian shore, it is also possible that the gyre circulation in the Norwegian Sea could contribute to the variability of the NwASC. The spatial distribution of the barotropic streamfunction in the Norwegian Sea does show that part of the NwASC participates to the model gyre circulation, and the different wind curl patterns between the 
first and the second periods (Fig. 11c and d) could drive different responses of this large scale circulation. We indeed observe a loss of correlation between the PC associated with the first loading pattern of the barotropic streamfunction and the NwASC transport between the first and second sub-period (correlation of 0.81 prior to 1996 drops down to 0.37 (not significant) afterwards). This loss of correlation would be consistent with a scenario in which a weakened variability of gyre circulation in the eastern Norwegian Sea during the second period would tend to be less influential on the Norwegian slope current.

The change in the wind pattern responsible for driving the interannual variability of the NwASC winter transport in the mid-1990s (Figures $7 \mathrm{~b}$ and 12a) is not found for the monthly variability of the current. The wind pattern driving the monthly variability of the transport is characterized by southwesterly winds along the Norwegian coast, over both sub-periods (Figure 12b); the wind patterns associated with the monthly and interannual variability are thus quite different over the second period. This difference was previously noted by Chafik et al. (2015), though over a slightly different period (1993-2012), and may be explained by the fact that the intraseasonnal variability in winter is weaker prior to the mid-1990s. Monthly southwesterly wind anomalies during the winter period show persistence of at least 2 months during the first sub-period, while they are uncorrelated amongst themselves during the second sub-period.

Passive tracer experiments allow us to estimate the impact of the change in circulation variability on the evolution of water properties. Contrasting the propagation of a tracer launched in the FSC between the two sub-periods, an increased accumulation of tracer is found in the cyclonic gyre in the southern Norwegian Sea during the second period (Figure 13a), which would suggest that more Atlantic Water became trapped into the gyre. Indeed, the temperature averaged over the upper $500 \mathrm{~m}$ of the gyre is about $0.7^{\circ} \mathrm{C}$ higher in the second sub-period. The same feature is obtained with the tracer source located over the IFR. 
Concomitantly with both the Norwegian gyre (Skagseth and Mork, 2012; Mork et al., 2014) and the NwAC (Skagseth et al., 2008) showing a warming after the mid-1990s, we show from observations (Figure 13c) and model results (Figure 13b) that the warming is enhanced in the western part of the Svinoy section which crosses the NwAFC and the eastern Norwegian Sea gyre. This feature may suggest that the warming trend observed in the AW in the Faroe Current after the mid-1990s (Hansen et al., 2015) might have been attenuated farther north by increased heat exchanges between the NwAFC and the gyre interior.

The shift in the subpolar gyre circulation in the mid-1990s was attributed to changes in the surface heat fluxes and wind stress curl over the northern North Atlantic (Häkkinen and Rhines, 2004; Hàtun et al., 2005; Herbaut and Houssais, 2009). According to the present analysis, these changes were accompanied by a spatial shift in the loading patterns of the SLP variability over the Norwegian Sea (Figure $11 \mathrm{a}$ and b). This shift may be interpreted as being the result of increased occurrence of the Atlantic Ridge (AR) weather regime after 1996 (as evidenced, e.g., in Fig. 4e of Barrier et al., 2015). The AR weather regime is indeed characterized by a strong, large scale component of the wind perpendicular to the Norwegian coast. Enhanced influence of the AR regime after the mid-1990s would be consistent with the increased frequency of blocking events over the British Isles (which have been associated with occurrences of the Atlantic Ridge regime) during the 2000s (Häkkinen et al. 2011b).

\section{Summary and conclusion}

A change in the circulation of the Atlantic water in the Nordic Seas is found in the mid-1990s in a hindcast simulation of the period 1979-2012. Prior to 1996, a large scale mode, linking the variations of the AW inflow in the FSC to those in the NwASC, the WSC and the AW inflow at BSO, dominates the variability of the circulation. In contrast, after the mid-1990s, the variations of the $\mathrm{NwAC}$ are mainly associated with its offshore branch, the correlation 
between the AW inflow at FSC and the NwASC is no longer significant, the NwASC is mainly influenced by the AW branch recirculating in the North Sea, and current velocity anomalies along the southern and western slopes of the Svalbard continental shelf represent the main mode of variability in the northern Norwegian Sea and the Barents Sea. Changes in the wind forcing associated with the NAO explain this circulation change. The latter is found to reduce the impact of heat anomalies in the AW entering the Greenland Scotland Ridge onto the AW current farther north.

While the decadal to multi-decadal variability of the NAO index has already been shown to have a strong impact on the Atlantic Meridonal Overturning Circulation (MOC) and the associated meridional heat transport (Delworth and Zeng, 2016), the present study suggests that changes in the NAO SLP pattern (and related surface winds) might also be influential to the upper limb of the MOC as far north as in the Nordic Seas.

This study has been performed with an eddy permitting model. However, observations from drifters or satellite altimetry suggest strong eddy activity along the NwAC throughout the period considered in the present study (Koszalka et al., 2011; Andersson et al. 2011), particularly in the Lofoten Basin area (Isachsen, 2015). (Note however that the observations examined in these studies do not cover the period prior to 1990). Ocean simulations at higher resolution would be needed to investigate whether the identified change in the mean winter AW circulation might have influenced the eddy activity in the Nordic Seas, and how the eddy activity may have affected the co-variability between the various AW branches.

Acknowledgement: The research leading to these results has received funding from the European Union 7th Framework Programme (FP7 2007-2013) under grant agreement n.308299, NACLIM Project. Both the data and input files necessary to reproduce the experiments with the model, are available from the authors upon request (ch@locean- 
ipsl.upmc.fr). This work was granted access to the HPC resources of CINES under the allocation 20100239 made by GENCI. This research also benefited from the Drakkar project which provided the fields for the open boundary conditions. The authors would like to thank Jean Marc Molines and Christian Ethé for their help to set-up the model configuration and two anonymous reviewers for their valuable comments and suggestions.
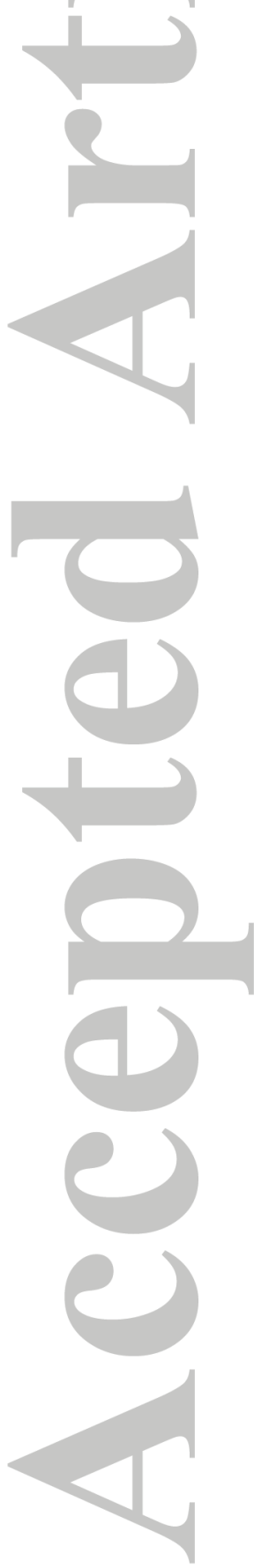


\section{References:}

Andersson, M., K. A. Orvik, J. H. LaCasce, I. Koszalka, and C. Mauritzen (2011), Variability of the Norwegian Atlantic Current and associated eddy field from surface drifters, J. Geophys. Res., 116, C08032, doi:10.1029/2011JC007078.

Årthun, M., T. Eldevik, L. H. Smedsrud, Ø. Skagseth, and R. Ingvaldsen, 2012: Quantifying the influence of Atlantic heat on Barents Sea ice variability and retreat, J. Clim., 25, 4736-4743, doi:10.1175/JCLI-D-11-00466.1.

Barrier, N., J. Deshayes, A.-M. Treguier, and C. Cassou, 2015 Heat Budget in the North Atlantic Subpolar Gyre: Impacts of Atmospheric Weather Regimes on the 1995 Warming Event ». Progress in Oceanography,130, 7590. doi:10.1016/j.pocean.2014.10.001.

Berx, B., Hansen, B., Østerhus, S., Larsen, K. M., Sherwin, T., and Jochumsen, K., 2013: Combining in situ measurements and altimetry to estimate volume, heat and salt transport variability through the Faroe-Shetland Channel, Ocean Sci., 9, 639-654, doi:10.5194/os-9-639-2013.

Carmack, E., and Coauthors, 2015: Toward quantifying the increasing role of oceanic heat in sea ice loss in the new Arctic. Bull. Amer. Meteor. Soc., 96, 2079-2105, doi:10.1175/BAMS-D-1300177.1.

Carton, J. A., G. A. Chepurin, J. Reagan, and S. Häkkinen, 2011: Interannual to decadal variability of Atlantic Water in the Nordic and adjacent seas. J. Geophys. Res., 116, C11035, doi:10.1029/2011JC007102

Childers, K. H., C. N. Flagg, and T. Rossby (2014), Direct velocity observations of volume flux between Iceland and the Shetland Islands, J. Geophys. Res. Oceans, 119, 5934-5944, doi: $10.1002 / 2014 \mathrm{JC} 009946$

Chafik, L., J. Nilsson, Ø. Skagseth, and P. Lundberg (2015), On the flow of Atlantic water and temperature anomalies in the Nordic Seas toward the Arctic Ocean, J. Geophys. Res. Oceans, 120, 7897-7918, doi:10.1002/2015JC011012.

Davini, P., C. Cagnazzo, R. Neale, and J. Tribbia (2012), Coupling between Greenland blocking and the North Atlantic Oscillation pattern, Geophys. Res. Lett., 39, L14701, doi:10.1029/2012GL052315. 
Delworth, T. L., and F. Zeng, 2016: The Impact of the North Atlantic Oscillation on Climate through Its Influence on the Atlantic Meridional Overturning Circulation ». Journal of Climate 29, 94162. doi:10.1175/JCLI-D-15-0396.1.

Dmitrenko I. A. , S.A. Kirillov, N. Serra, N.V. Koldunov, V.V. Ivanov, U. Schauer, I.V. Polyakov, D.G. Barber, M. Janout, V.S. Lien, M. Makhotin, Y. Aksenov: Heat loss from the Atlantic water layer in the St. Anna Trough (northern Kara Sea): causes and consequences Ocean Sciences, 10 (2014), pp. 719-730 http://dx.doi.org/10.5194/0s=10-719-2014

Dee, D. P., et al., 2011: The ERA-interim reanalysis: Configuration and performance of the data assimilation system,. Q. J. R. Meteorol. Soc., 137, 553-597. doi: 10.1002/qj.828.

Fichefet, T., and M.A. Morales Maqueda, 1997: Sensitivity of a global sea ice model to the treatment of ice thermodynamics and dynamics. J. Geophys. Res., 102, 12,60912,646.

Häkkinen, S., P. B. Rhines, and D. L. Worthen: 2011a, Warm and Saline Events Embedded in the Meridional Circulation of the Northern North Atlantic. Journal of Geophysical Research 116, doi:10.1029/2010JC006275.

Häkkinen, S., P. B. Rhines, and D. L. Worthen, 2011b: Atmospheric Blocking and Atlantic Multidecadal Ocean Variability. Science, 334, 6056, 655-659, doi: 10.1126/science.1205683

Hakkinen, S., and P. B. Rhines (2004), Decline of subpolar North Atlantic gyre circulation during the 1990s, Science, 304, 555-559, doi:10.1126/science.1094917.

Hansen, B., K. M. H. Larsen, H. Hátún, R. Kristiansen, E. Mortensen, and S. Østerhus, 2015: Transport of Volume, Heat, and Salt towards the Arctic in the Faroe Current 1993-2013. Ocean Science 11, no 5, 74357. doi:10.5194/os-11-743-2015.

Hansen, B., Hátún, H., Kristiansen, R., Olsen, S. M., and Østerhus, S., 2010: Stability and forcing of the Iceland-Faroe inflow of water, heat, and salt to the Arctic, Ocean Sci., 6, 1013-1026, doi:10.5194/os-6-1013-2010.

Hátún, H., A. B. Sandø, H. Drange, B. Hansen, and H. Valdimarsson (2005), Influence of the Atlantic subpolar gyre on the thermohaline circulation, Science, 309, 1841-1844, doi:10.1126/science.1114777. 
Herbaut, C., Houssais, M.-N., Close, S. and Blaizot, A.-C. 2015. Two wind-driven modes of winter sea ice variability in the Barents Sea. Deep. Sea Res. I. 106, 97-115. doi: http://dx.doi.org/10.1016/j.dsr.2015.10.005

Herbaut, C., and M.-N. Houssais (2009), Response of the eastern North Atlantic subpolar gyre to the North Atlantic Oscillation, Geophys. Res. Lett., 36, L17607, doi:10.1029/2009GL039090.

Høydalsvik, F., C. Mauritzen, K.A. Orvik, J.H. LaCasce, C.M. Lee, J. Gobat, 2013 : Transport estimates of the Western Branch of the Norwegian Atlantic Current from glider surveys. Deep Sea Res., I, doi.org/10.1016/j.dsr.2013.05.005

Hurrell J., and C. Deser:, 2009: North Atlantic climate variability: The role of the North Atlantic Oscillation. J. Marine Sys., 79, 3-4, 231-244. doi.10.1016/j.jmarsys.2008.11.026

Hurrell J. W, 1995: Decadal trends in the North Atlantic Oscillation, regional temperatures and precipitation. Science, 269, pp. 676-679

Ingvaldsen, R., L. Asplin, and H. Loeng, 2004: The seasonal cycle in the Atlantic transport to the Barents Sea during the years 1997-2001, Cont. Shelf Res., 24, 1015-1032.

Isachsen, P. E. (2015), Baroclinic instability and the mesoscale eddy field around the Lofoten Basin, J. Geophys. Res. Oceans, 120, 2884-2903, doi:10.1002/2014JC010448.

Karcher, M., A. Beszczynska-Möller, F. Kauker, R. Gerdes, S. Heyen, B. Rudels, and U. Schauer, 2011; Arctic Ocean Warming and Its Consequences for the Denmark Strait Overflow ». Journal of Geophysical Research 116, no C2, doi:10.1029/2010JC006265.

Karcher, M. J., R. Gerdes, F. Kauker, and C. Köberle, 2003: « Arctic Warming: Evolution and Spreading of the 1990s Warm Event in the Nordic Seas and the Arctic Ocean, Journal of Geophysical Research: Oceans 108, no C2, doi:10.1029/2001JC001265.

Koszalka, I., J.H. LaCasce, M. Andersson, K.A. Orvik, and C. Mauritzen, 2011: Surface Circulation in the Nordic Seas from Clustered Drifters ». Deep Sea Res. I: 58,: 46885. doi:10.1016/j.dsr.2011.01.007.

Larsen, K., H. Hátún, B. Hansen, and R. Kristiansen, 2012: Atlantic Water in the Faroe Area: Sources and Variability. ICES Journal of Marine Scienc,, fss028. doi:10.1093/icesjms/fss028. 
Lien, V., F. B. Vikebø, and Ø. Skagseth. 2013: One mechanism contributing to co-variability of the Atlantic inflow branches to the Arctic. Nature Communications 4:1488. doi: $10.1038 /$ ncomms 2505 .

Madec, G., 2008: "NEMO ocean engine", Note du pôle de modélisation. Institut Pierre Simon Laplace (IPSL), France. No 27 ISSN No 1288-1619.

Mork, K. A., Ø. Skagseth, V. Ivshin, V. Ozhigin, S. L. Hughes, and H. Valdimarsson (2014), Advective and atmospheric forced changes in heat and fresh water content in the Norwegian Sea, 1951-2010, Geophys. Res. Lett., 41, 6221-6228, doi:10.1002/2014GL061038.

Nakanowatari T., K. Sato, and J. Inoue, 2014: Predictability of the Barents Sea Ice in Early Winter: Remote Effects of Oceanic and Atmospheric Thermal Conditions from the North Atlantic. J. Climate, 27, 8884-8901. doi: 10.1175/JCLI-D-14-00125.1

Onarheim, I. H., T. Eldevik, M. Årthun, R. B. Ingvaldsen, and L. H. Smedsrud (2015), Skillful prediction of Barents Sea ice cover, Geophys. Res. Lett., 42, 5364-5371, doi:10.1002/2015GL064359.

Orvik, K. A., and P. Niiler, 2002: Major pathways of Atlantic water in the northern North Atlantic and Nordic Seas toward Arctic, Geophys. Res. Lett., 29(19), 1896, doi:10.1029/2002GL015002.

Orvik, K. A., and Ø. Skagseth (2005), Heat flux variations in the eastern Norwegian Atlantic Current toward the Arctic from moored instruments, 1995-2005, Geophys. Res. Lett., 32, L14610, doi: $10.1029 / 2005 \mathrm{GL} 023487$.

Østerhus, S., W. R. Turrrell, S. Jónsson, and B. Hansen (2005), Measured volume, heat, and salt fluxes from the Atlantic to the Arctic Mediterranean, Geophys. Res. Lett., 32, L07603, doi:10.1029/2004GL022188.

Pinto, J. G. and Raible, C. C. (2012), Past and recent changes in the North Atlantic oscillation. WIREs Clim Change, 3: 79-90. doi: 10.1002/wcc.150

Polyakov, I. V., and Coauthors, 2010: Arctic Ocean warming contributes to reduced polar ice cap. J. Phys. Oceanogr., 40, 2743-2756, doi:10.1175/2010JPO4339.1

Richter, K., O. H. Segtnan, and T. Furevik. 2012 Variability of the Atlantic Inflow to the Nordic Seas and Its Causes Inferred from Observations of Sea Surface Height». Journal of Geophysical Research: Oceans 117, no C4, doi:10.1029/2011JC007719. 
Richter, K. and S. Maus, 2011: Interannual Variability in the Hydrography of the Norwegian Atlantic Current: Frontal versus Advective Response to Atmospheric Forcing. Journal of Geophysical Research 116, no C12, doi:10.1029/2011JC007311.

Richter, K., T. Furevik, and K. A. Orvik, 2009: Effect of Wintertime Low-Pressure Systems on the Atlantic Inflow to the Nordic Seas. Journal of Geophysical Research 114, no C9, doi:10.1029/2009JC005392.

Rigor, I. G., J. M. Wallace, and R. L. Colony, 2002: Response of sea-ice to the Arctic Oscillation, J. Clim., 15, 2648-2663 doi:10.1175/1520-0442(2002)015<2648:ROSITT> 2.0.CO;2

Rossby, T., M. D. Prater, and H. Søiland (2009), Pathways of inflow and dispersion of warm waters in the Nordic seas, J. Geophys. Res., 114, C04011, doi:10.1029/2008JC005073.

Rossow, W.B., and Schiffer, R.A., 1999: Advances in Understanding Clouds from ISCCP. Bull. Amer. Meteor. Soc., 80, 2261-2288. doi: 10.1175/15200477(1999)080<2261:AIUCFI >2.0.CO;2

Sandø, A. B., and T. Furevik (2008), Relation between the wind stress curl in the North Atlantic and the Atlantic inflow to the Nordic Seas, J. Geophys. Res., 113, C06028, doi: $\underline{10.1029 / 2007 \mathrm{JC} 004236}$.

Sandø, A. B., J. E. Ø. Nilsen, T. Eldevik, and M. Bentsen (2012), Mechanisms for variable North Atlantic-Nordic seas exchanges, J. Geophys. Res., 117, C12006, doi:10.1029/2012JC008177.

Sandø, A. B., Y. Gao, and H. R. Langehaug, 2014: Poleward ocean heat transports, sea ice processes, and Arctic sea ice variability in NorESM1-M simulations, J. Geophys. Res. Oceans, 119, 20952108, doi:10.1002/2013JC009435.

Schlichtholz, P., 2011: Influence of oceanic heat variability on sea ice anomalies in the Nordic Seas. Geophys. Res. Lett., 38, L05705, doi:10.1029/2010GL045894.

Serra, N., R.H. Käse, A. Köhl, D. Stammer, and D. Quadfasel, 2010: On the Low-Frequency Phase Relation between the Denmark Strait and the Faroe-Bank Channel Overflows: Tellus A 62, 53050. doi:10.1111/j.1600-0870.2010.00445.x. 
Sherwin, T., J., S. Hughes, W. Turrell, B. Hansen, S. Østerhus: 2008 Wind-driven monthly variations in transport and the flow field in the Faroe-Shetland Channel. Polar Research, v. 27, n. 1, p. 7-22, apr. 2008. ISSN 1751-8369.

Skagseth, Ø., and K. A. Mork (2012), Heat content in the Norwegian Sea, 1995-2010, ICES J. Mar. Sci., 69(5), 826-832.

Skagseth, Ø., K. F. Drinkwater, and E. Terrile, 2011: Wind- and buoyancy-induced transport of the Norwegian Coastal Current in the Barents Sea, J. Geophys. Res., 116,C08007,doi:10.1029/2011JC006996.

Skagseth, Ø., T. Furevik, R. Ingvaldsen, H. Loeng, K. A. Mork, K. A. Orvik, and V. Ozhigin, 2008: Volume and heat transports to the Arctic Ocean via the Norwegian and Barents Seas, in Arctic Subarctic Ocean Fluxes: Defining the Role of the Northern Seas in Climate, edited by R. Dickson, J. Meincke, and P. Rhines, Springer, pp. 45-64, New York.

Skagseth, Ø. (2008), Recirculation of Atlantic Water in the western Barents Sea, Geophys. Res. Lett., 35, L11606, doi:10.1029/2008GL033785.

Skagseth, Ø. (2004), Monthly to annual variability of the Norwegian Atlantic slope current: Connection between the northern North Atlantic and the Norwegian Sea, Deep Sea Res., Part I, $51(3), 349-366$.

Steele, M., R. Morley, and W. Ermold, 2001: PHC: A global ocean hydrography with a high quality Arctic Ocean, J. Climate, 14, 2079-2087. doi: 10.1175/15200442(2001)014<2079:PAGOHW>2.0.CO;2

Thierry, V., E. de Boisséson, and H. Mercier (2008), Interannual variability of the Subpolar Mode Water properties over the Reykjanes Ridge during 1990-2006, J. Geophys. Res., 113, C04016, doi: $10.1029 / 2007 J C 004443$.

Tverberg, V., O. A. Nøst, C. Lydersen, and K. M. Kovacs (2014), Winter sea ice melting in the Atlantic Water subduction area, Svalbard Norway, J. Geophys. Res. Oceans, 119, 5945-5967, doi:10.1002/2014JC010013.

Walczowski W., Piechura J., 2007: Pathways of the Greenland Sea warming. Geophysical Research Letters, 34:L10608. doi:10.1029/2007GL029974. 
Walczowski, W., 2013: Frontal structures in the West Spitsbergen Current margins, Ocean Sci., 9, 957-975, doi:10.5194/os-9-957-2013.

Wallace, J. M., and D. S. Gutzler, 1981: Teleconnections in the Geopotential Height Field during the Northern Hemisphere Winter ». Monthly Weather Review 109, 784812. doi:10.1175/15200493(1981)109<0784:TITGHF>2.0.CO;2.

Winther, N. G., and J. A. Johannessen (2006), North Sea circulation: Atlantic inflow and its destination, J. Geophys. Res., 111, C12018, doi:10.1029/2005JC003310.

Woollings, T., C. Franzke, D. L. R. Hodson, B. Dong, E. A. Barnes, C. C. Raible, and J. G. Pinto, 2015: Contrasting Interannual and Multidecadal NAO Variability». Climate Dynamics 45, 53956. doi:10.1007/s00382-014-2237-y.

Zhang, X., A. Sorteberg, J. Zhang, R. Gerdes, and J. C. Comiso (2008), Recent radical shifts of atmospheric circulations and rapid changes in Arctic climate system, Geophys. Res. Lett., 35, L22701, doi: 10.1029/2008GL035607.

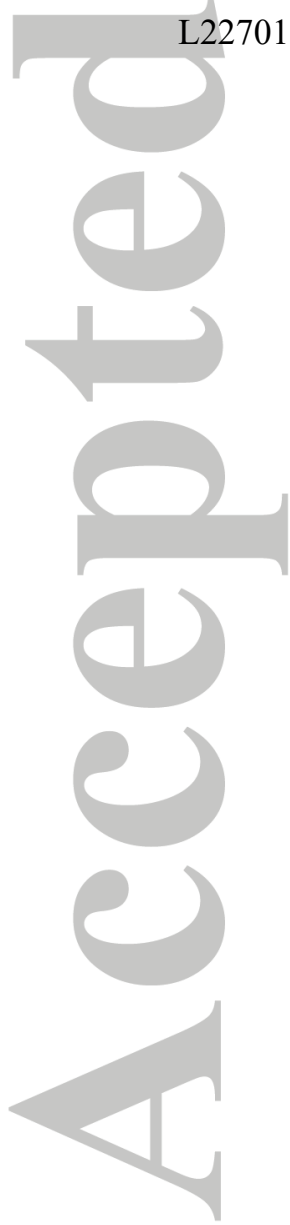


Figures Captions:

Figure 1: Bathymetry of the Nordic Seas. Schematic currents are based on the literature. Geographical features are labeled in black: Iceland-Faroe Ridge (IFR); Faroe Shetland Channel (FSC); Barents Sea Opening (BSO); Fram Strait; Norwegian Trench (NT), Bear Island (BI), Bear Island Trough (BIT). Currents are labeled in red and blue: Norwegian Atlantic Front Current (NwAFC); Norwegian Atlantic Slope Current (NwASC); West Spitsbergen Current (WSC).

Figure 2: Model velocity at $130 \mathrm{~m}$ averaged over the period 1979-2012. The red lines indicate the position of the Svinoy section, the BSO section and the $75^{\circ} \mathrm{N}$ section.

Figure 3: Mean winter (JFM) current velocity over the period 1979-2012, shown as the component normal to (a) the Svinoy section (C.I: $5 \mathrm{~cm} . \mathrm{s}^{-1}$ ), (b) the BSO section(C.I: $2.5 \mathrm{~cm} . \mathrm{s}^{-}$ ${ }^{1}$ ), and (c) the $75^{\circ} \mathrm{N}$ section(C.I: $2.5 \mathrm{~cm} \cdot \mathrm{s}^{-1}$ ). Positive values, which are associated with velocities into the figure, are in red and negative ones in blue. . See figure 2 for the location of the sections.

Figure 4: Temperature distribution along the Svinoy section for the periods prior to (a) and post (b) mid-1990s in the observations. (c) and (d) same as (a) and (b) for the model. (e-f) same as (a-d) for the section at $75^{\circ} \mathrm{N}$. Contour interval: $0.5^{\circ} \mathrm{C}$.

Figure 5: Mean winter (JFM) transports associated with the core of the NwASC (red) and the AW current at $75^{\circ} \mathrm{N}$ (blue) as well as the North Sea outflow through the Norwegian Trench (green). The time series are normalized. The mean and standard deviation are $3.1 \mathrm{~Sv}$ and 0.6 $\mathrm{Sv}$ for the outflow through the Norwegian Trench, $6 \mathrm{~Sv}$ and $1.45 \mathrm{~Sv}$ for the transport of the NwASC and 3.1 Sv and 1.2 Sv for the AW transport at $75^{\circ} \mathrm{N}$ in the upper $300 \mathrm{~m}$.

Figure 6: (a)-(b) First EOF of the mean winter (JFM) normal velocity through the Svinoy section over the period (a) 1979-1996 and (b) 1997-2012 (the black contour defines the zero isoline). (c)-(d) same as (a)-(b) for the section at $75^{\circ} \mathrm{N}$. Contour interval: $1 \mathrm{~cm} \cdot \mathrm{s}^{-1}$. Positive values, are in red and negative ones in blue. 
Figure 7: Regression of (a) the mean winter (JFM) current velocity at $130 \mathrm{~m}$, (b) the early winter (DJF) $10 \mathrm{~m}$ wind velocity and (c) the early winter (DJF) $10 \mathrm{~m}$ wind curl (unit: $10^{-5} \mathrm{~s}^{-1}$ ) onto PC1 of the normal velocity through the Svinoy section over the sub-period 1979-1996. The grey shading in (a) and (b) and the black contour in (c) define the areas of significance at $95 \%$ level.

Figure 8: Regression of the mean winter (JFM) current velocity at $130 \mathrm{~m}$ onto the PC1 of the normal velocity through the Svinoy section over the sub-period 1997-2012. The blue shading defines the areas of significance at $95 \%$ level.

Figure 9: Regression of (a) the mean winter (JFM) current velocity at $130 \mathrm{~m}$, (b) the early winter (DJF) $10 \mathrm{~m}$ wind, and (c) the early winter (DJF) $10 \mathrm{~m}$ wind curl (unit: $10^{-5} \mathrm{~s}^{-1}$ ) onto the inshore transport (see definition in text) of the AW current at $75^{\circ} \mathrm{N}$ over the period 1979 2012. The grey shading in (a) and (b) and the black contour in (c) define the areas of significance at $95 \%$ level.

Figure 10: Northeastward component of the mean winter (DJF) $10 \mathrm{~m}$ wind off Norway in the NCEP (blue) and ERAI (red) reanalyses. The wind has been averaged over the domain shown as a red box in Figure $7 \mathrm{~b}$.

Figure 11: First EOF of the early winter (DJF) SLP over the period (a) 1980-1996 and (b) 1997-2012. Regression of the $10 \mathrm{~m}$ wind curl onto the associated PC over the period (c) 19801996 and (d) 1997-2012. The black contours in (c) and (d) define the areas of significance at $95 \%$ level.

Figure 12: Regression of (a) the early winter (DJF) $10 \mathrm{~m}$ wind on the mean winter (JFM) transport of the NwASC and (b) the monthly $10 \mathrm{~m}$ wind at zero lag onto the monthly transport of the NwASC through the Svinoy section over the period 1997-2012.

Figure 13: (a) Difference in tracer concentration (unit: \%) between the second and the first sub-periods in the experiment with a tracer release at FSC (tracer concentrations have been averaged over the upper 600 meters of the water column). (b)-(c) Difference in temperature 
on the Svinoy section between the second and the first sub-periods in (b) the model (the hatched domain defines the area where the difference is significant at the $95 \%$ confidence level) and (c) the observations (extracted from the WOD data base).
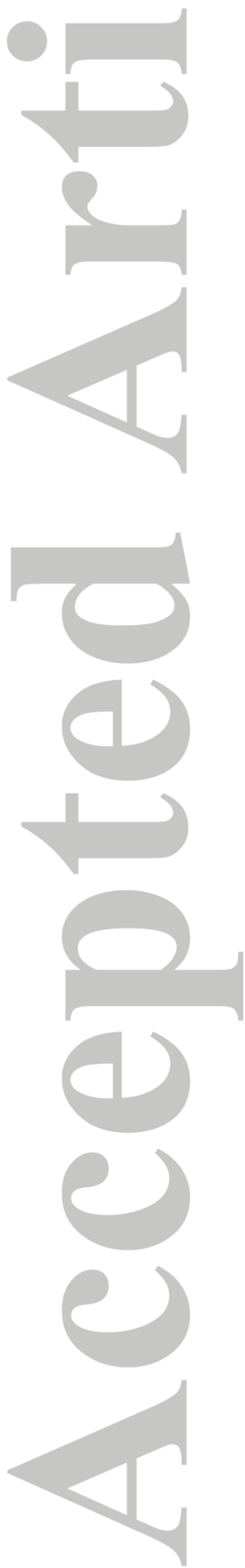
Figure - 1
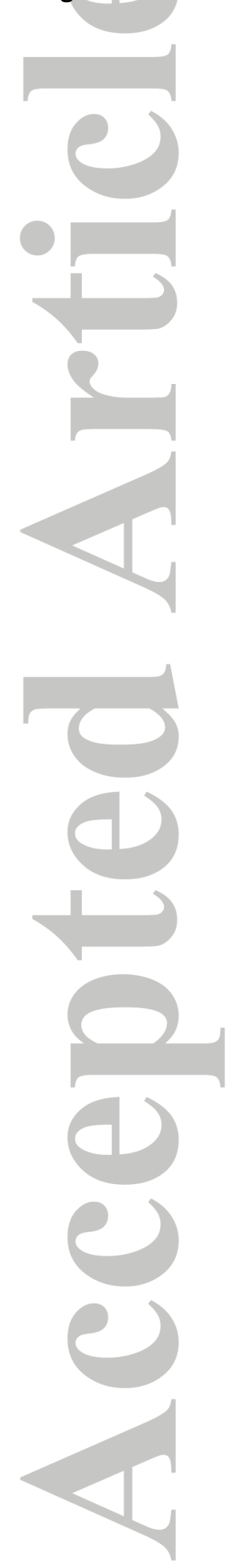

This article is protected by copyright. All rights reserved. 


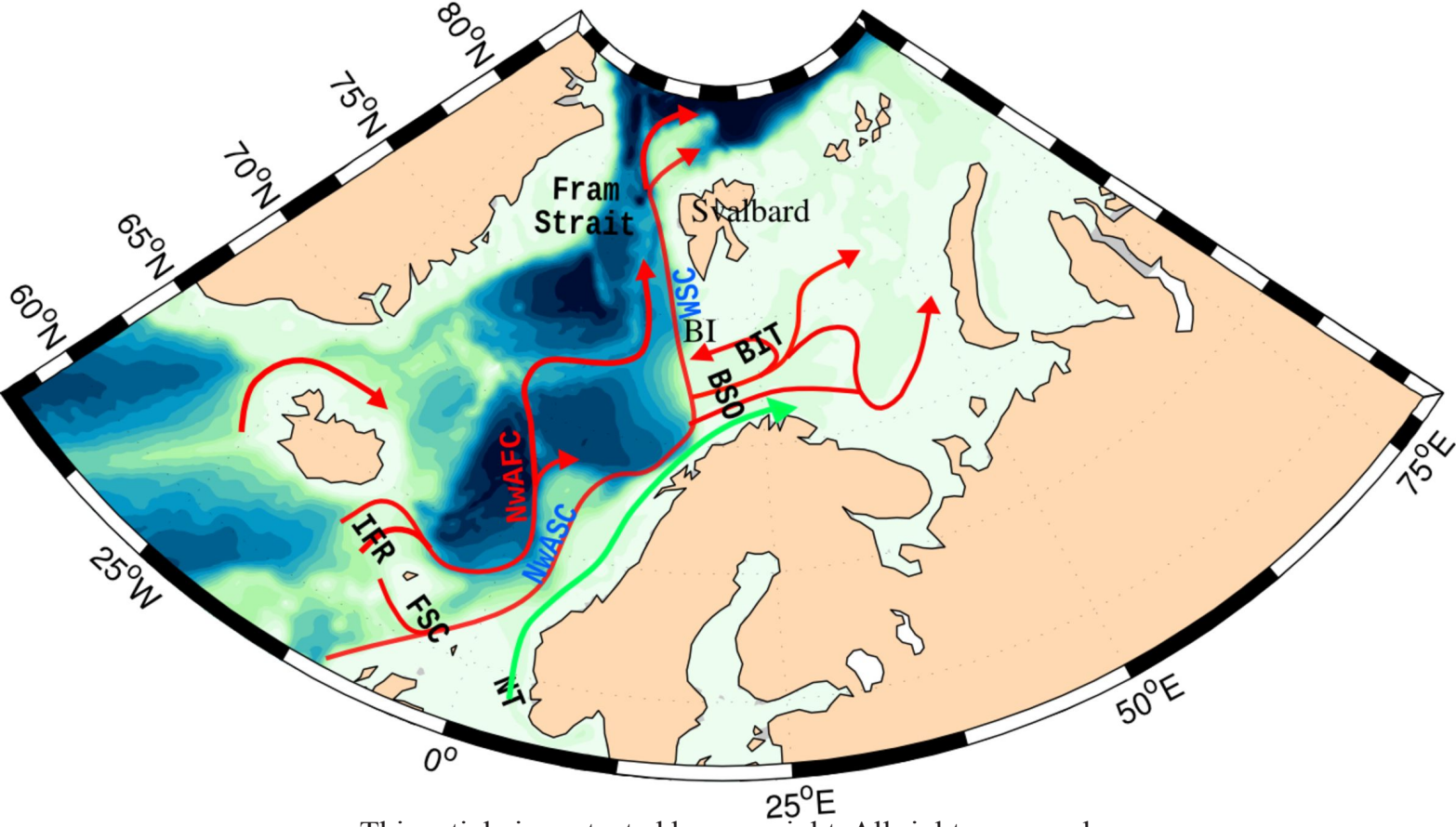

This article is protected by copyright. All rights reserved. 
Figure 2.
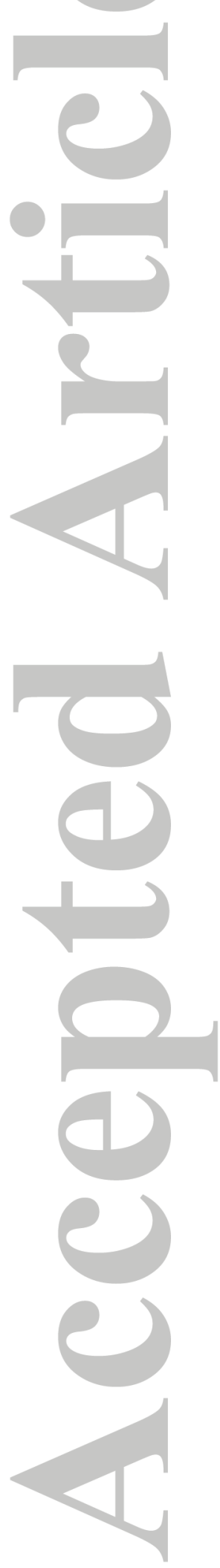

This article is protected by copyright. All rights reserved. 


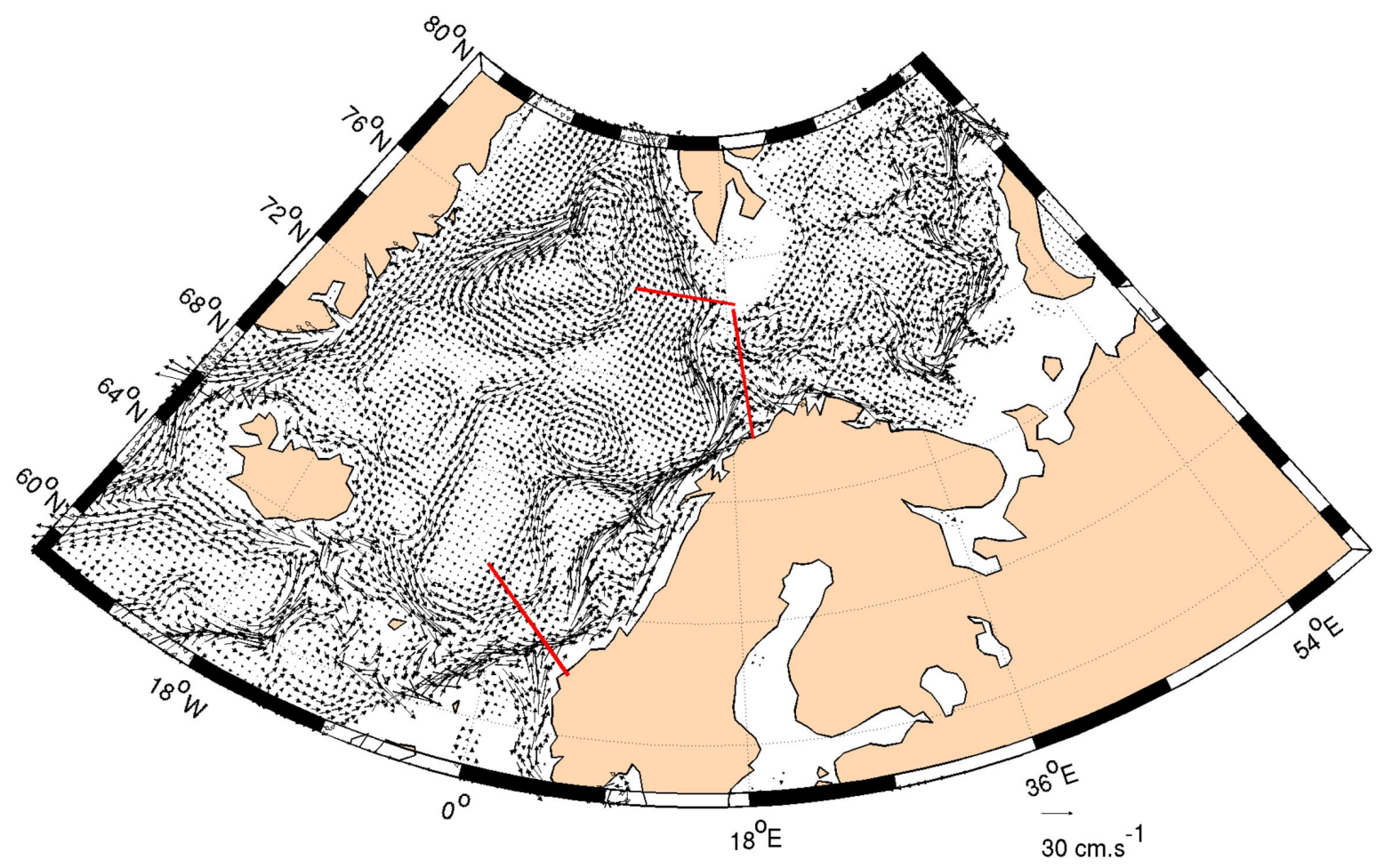


Figure 3.
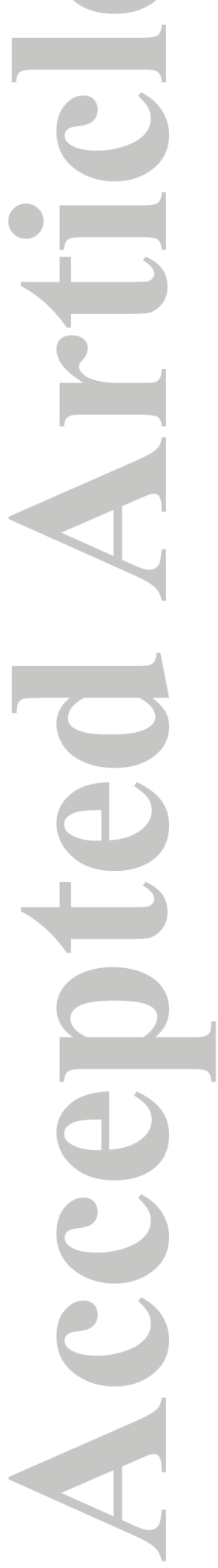

This article is protected by copyright. All rights reserved. 
a)

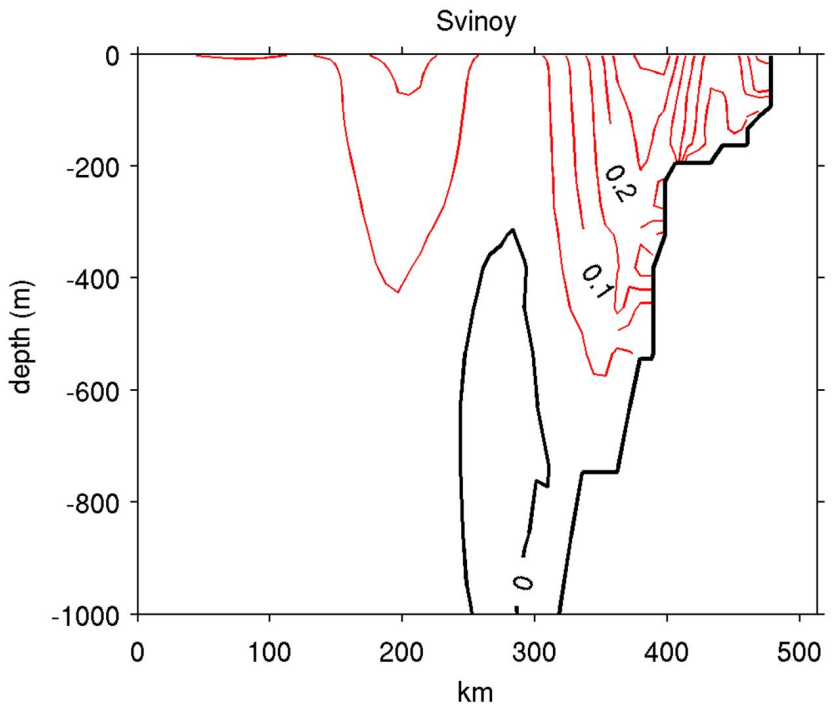

b)

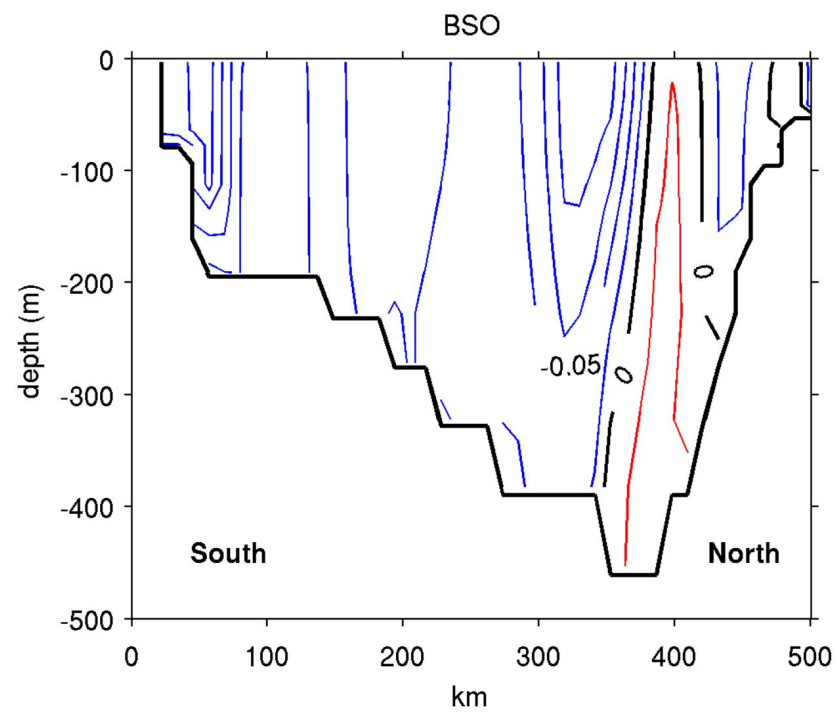

c)

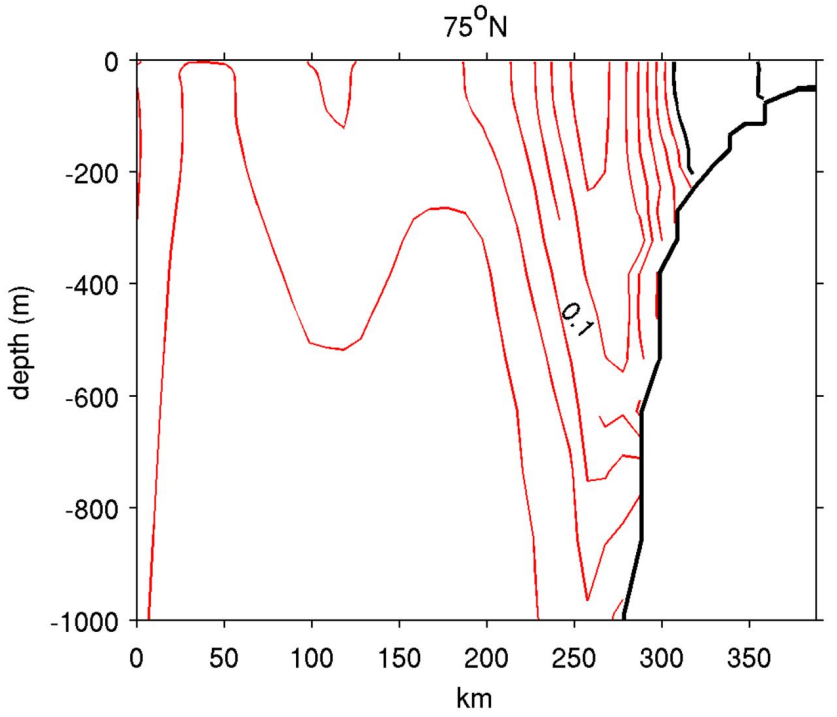

This article is protected by copyright. All rights reserved. 
Figure 4.
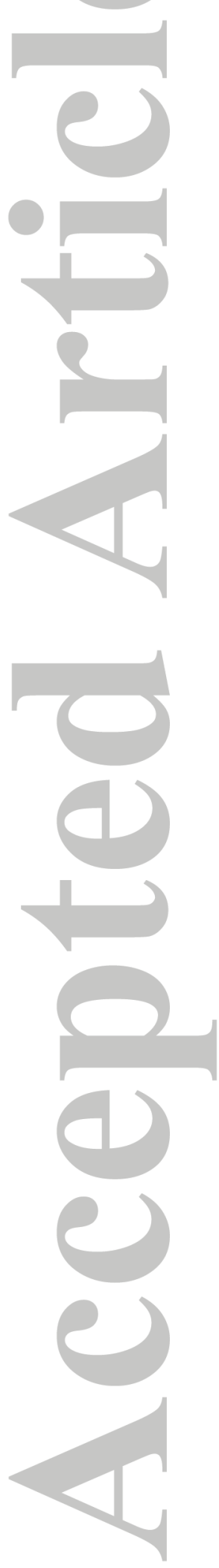

This article is protected by copyright. All rights reserved. 

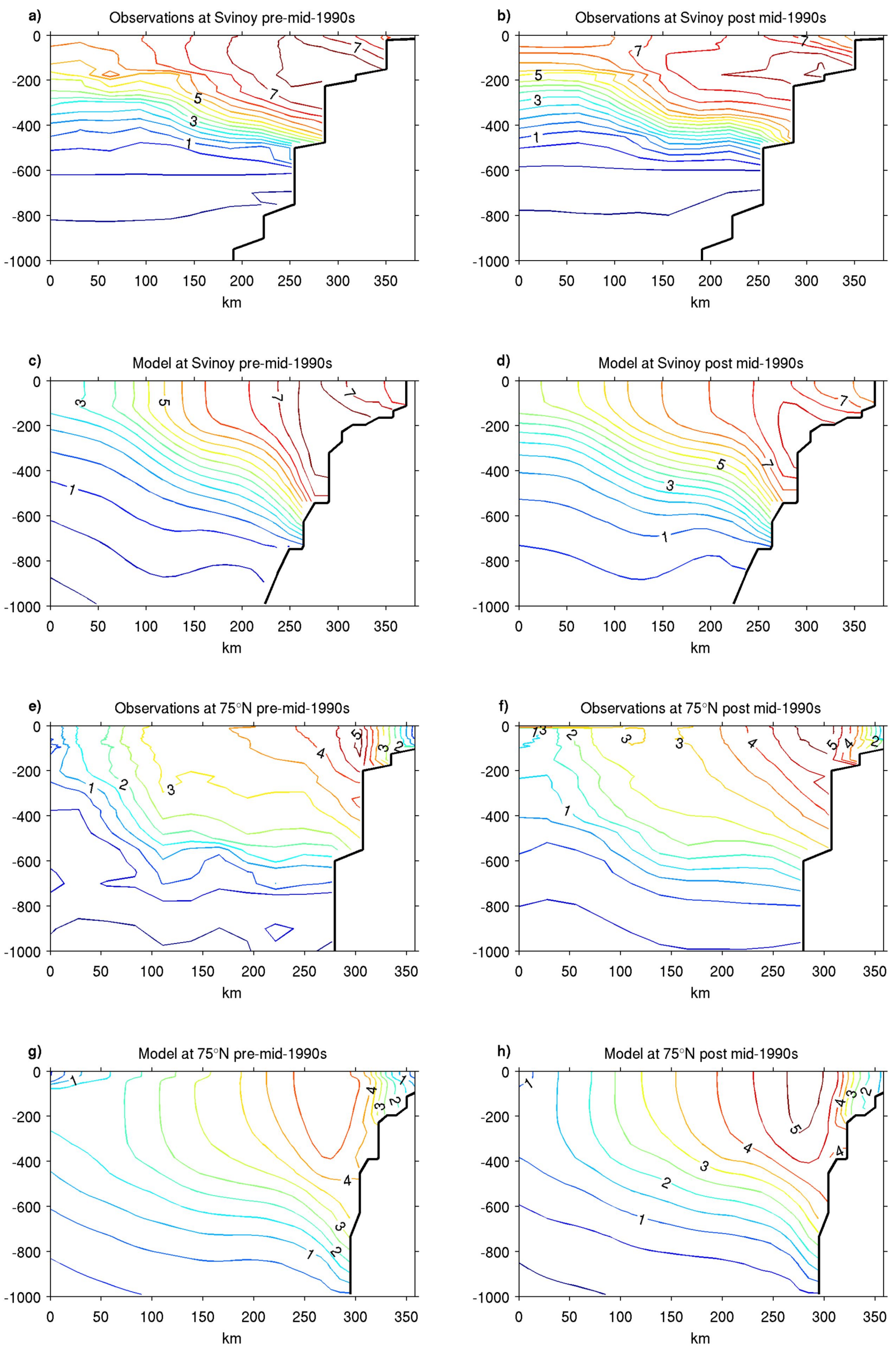

This article is protected by copyright. All rights reserved. 
Figure 5.
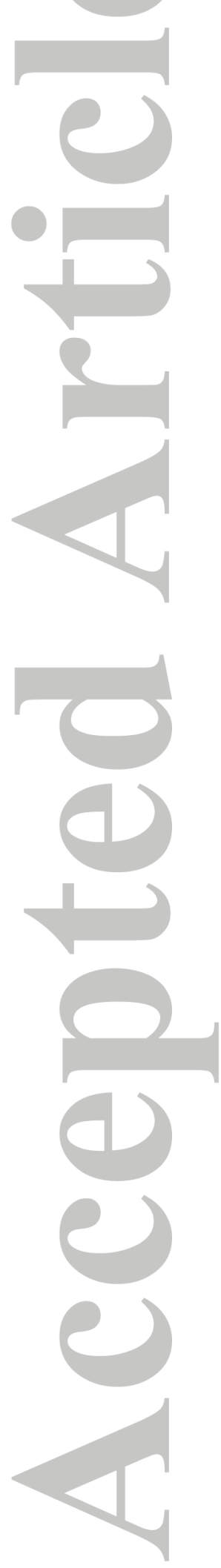

This article is protected by copyright. All rights reserved. 


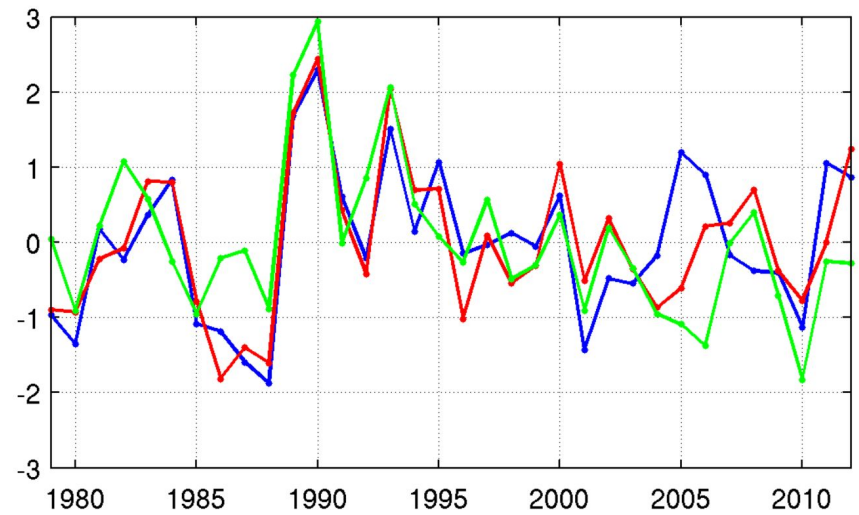

This article is protected by copyright. All rights reserved. 
Figure 6.
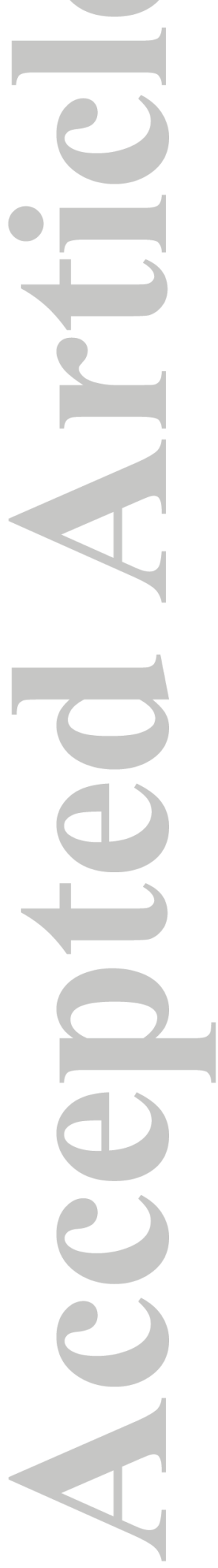

This article is protected by copyright. All rights reserved. 

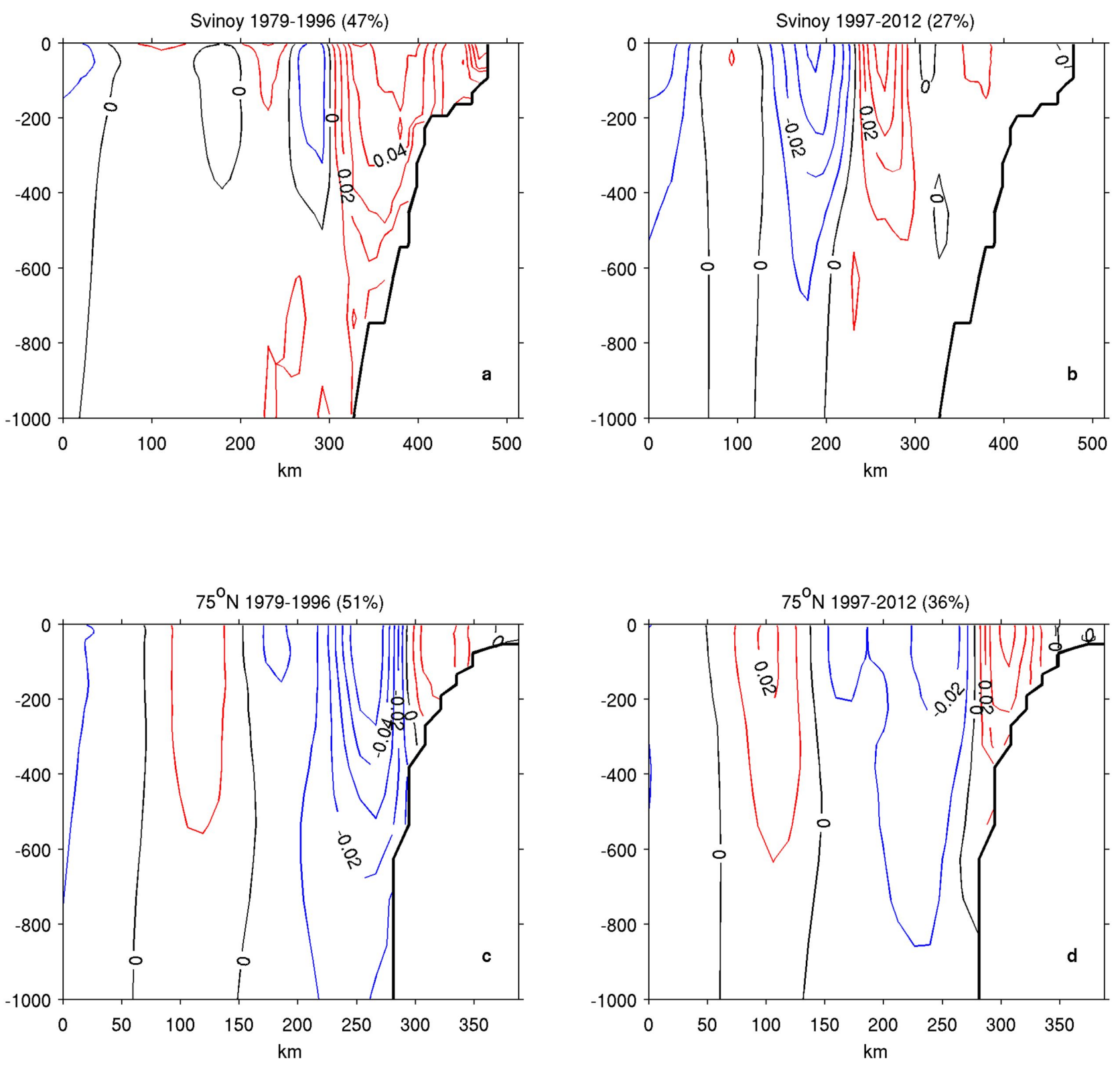

This article is protected by copyright. All rights reserved. 
Figure 7.
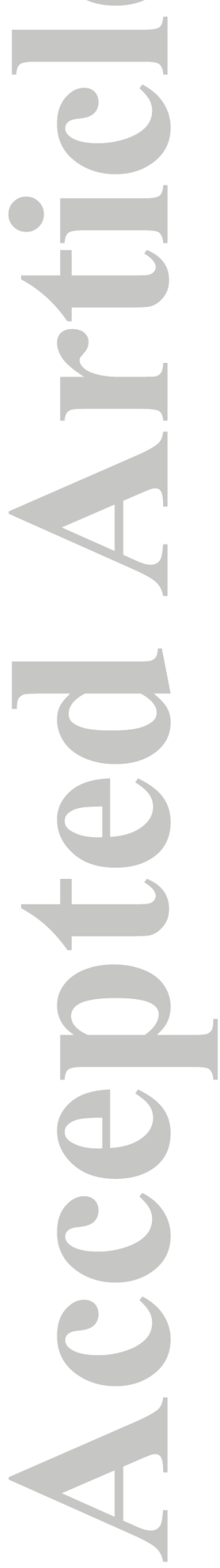

This article is protected by copyright. All rights reserved. 

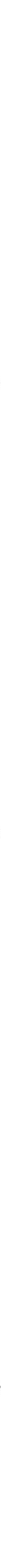

This article is protected by copyright. All rights reserved, 
Figure 8.
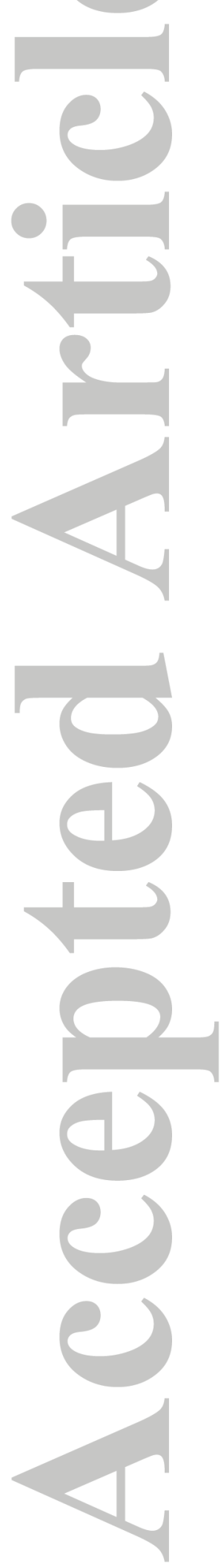

This article is protected by copyright. All rights reserved. 


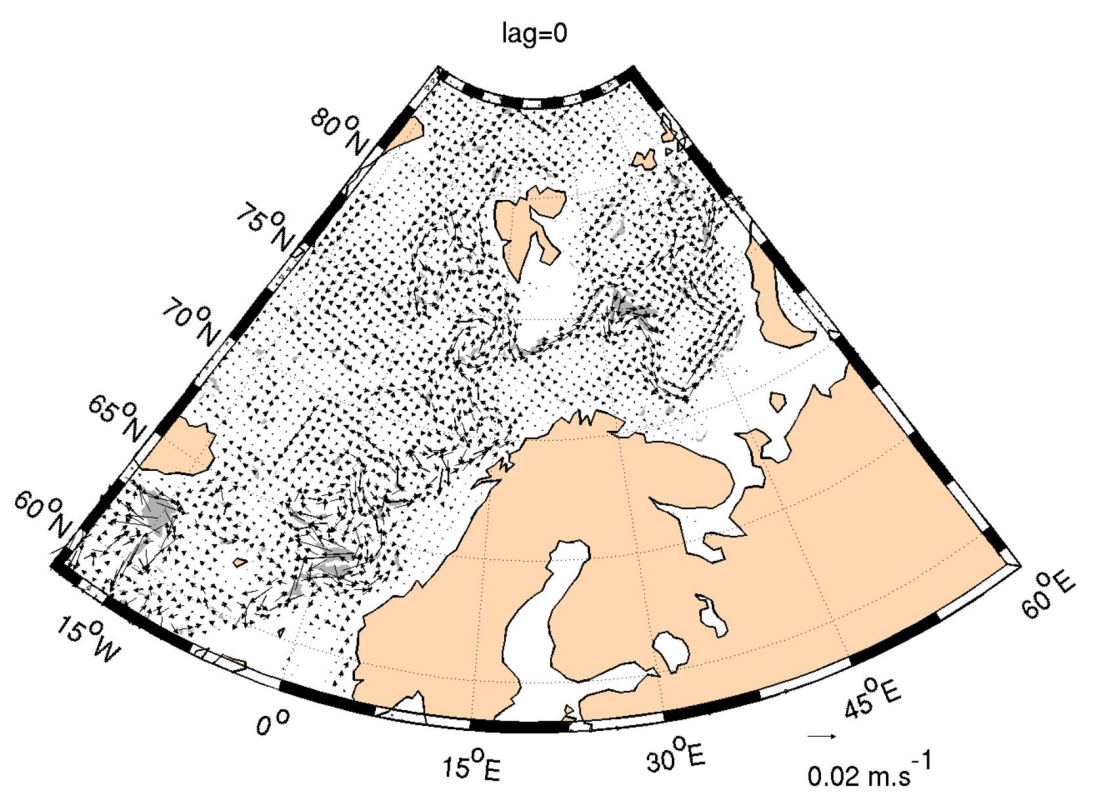

This article is protected by copyright. All rights reserved. 
Figure 9.
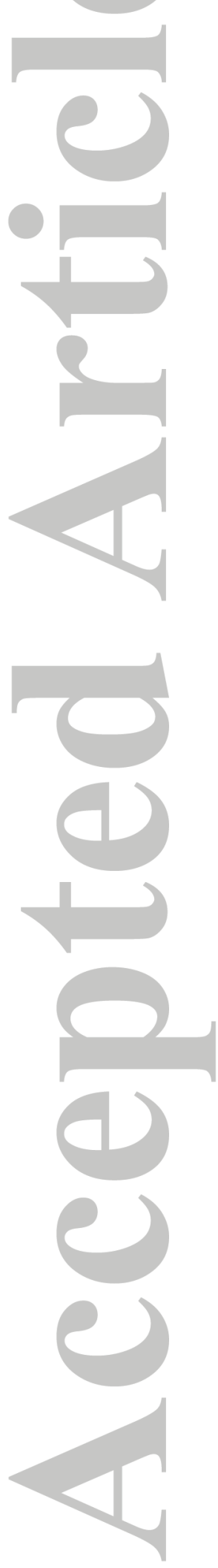

This article is protected by copyright. All rights reserved. 

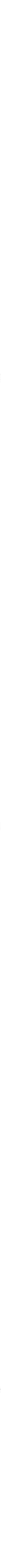

This article is protected by copyright. All rights reserved, 
Figure 10.
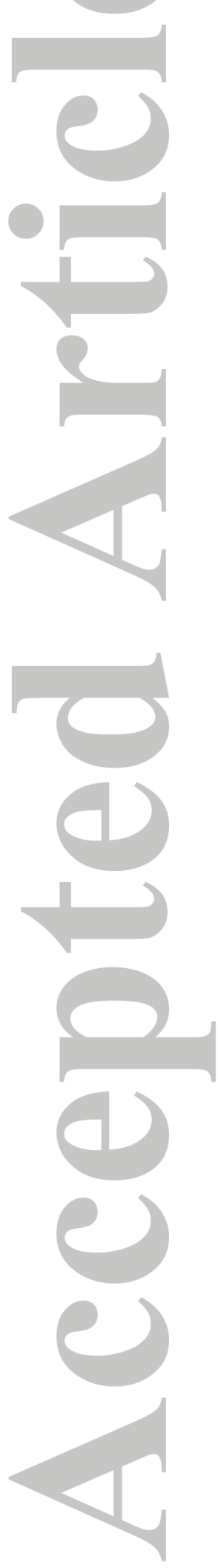

This article is protected by copyright. All rights reserved. 


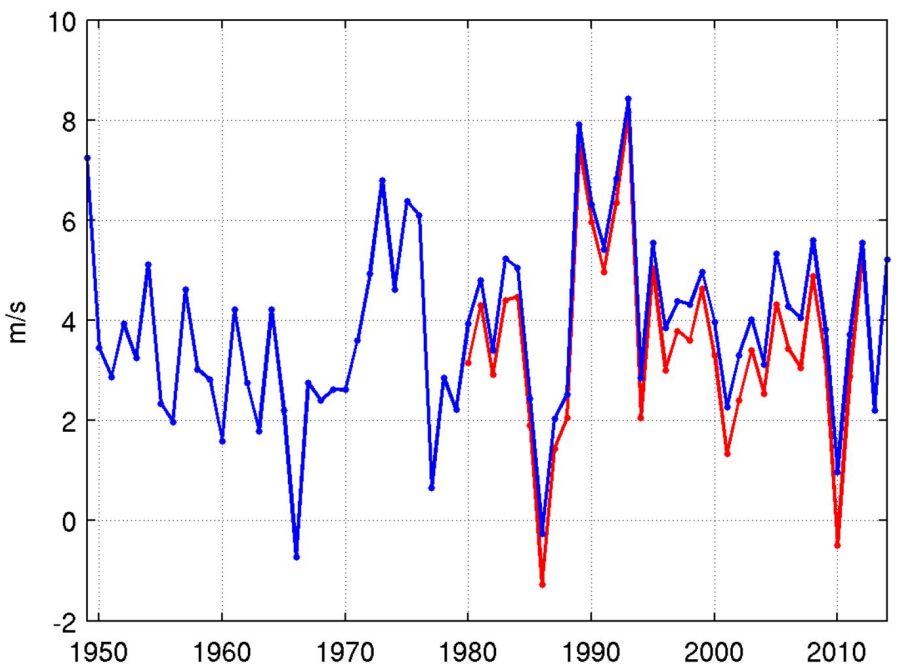

This article is protected by copyright. All rights reserved. 
Figure 11.
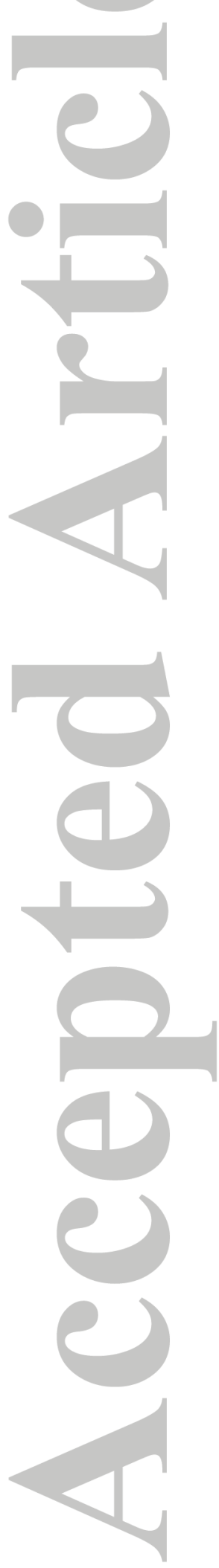

This article is protected by copyright. All rights reserved. 
a)
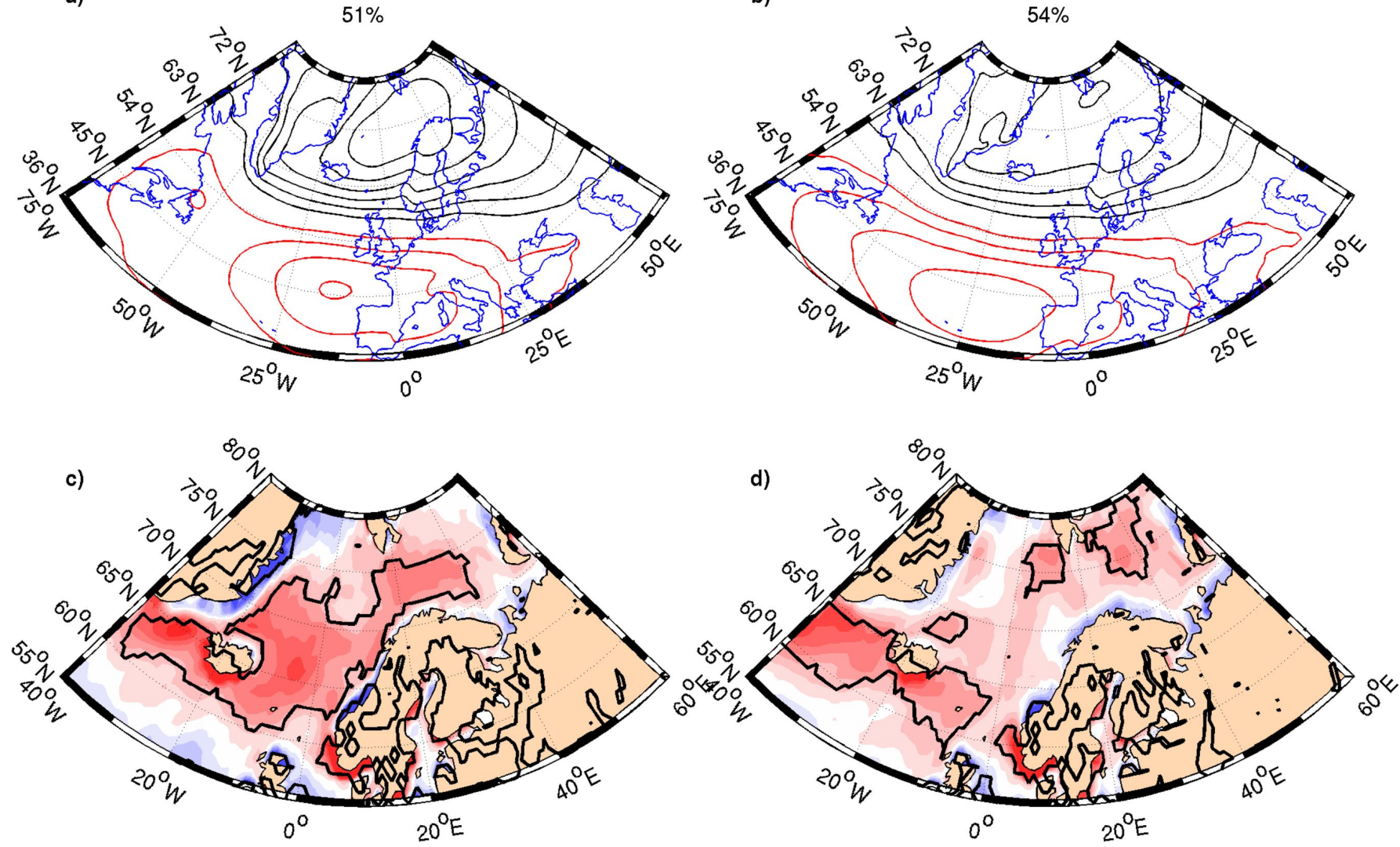

b)
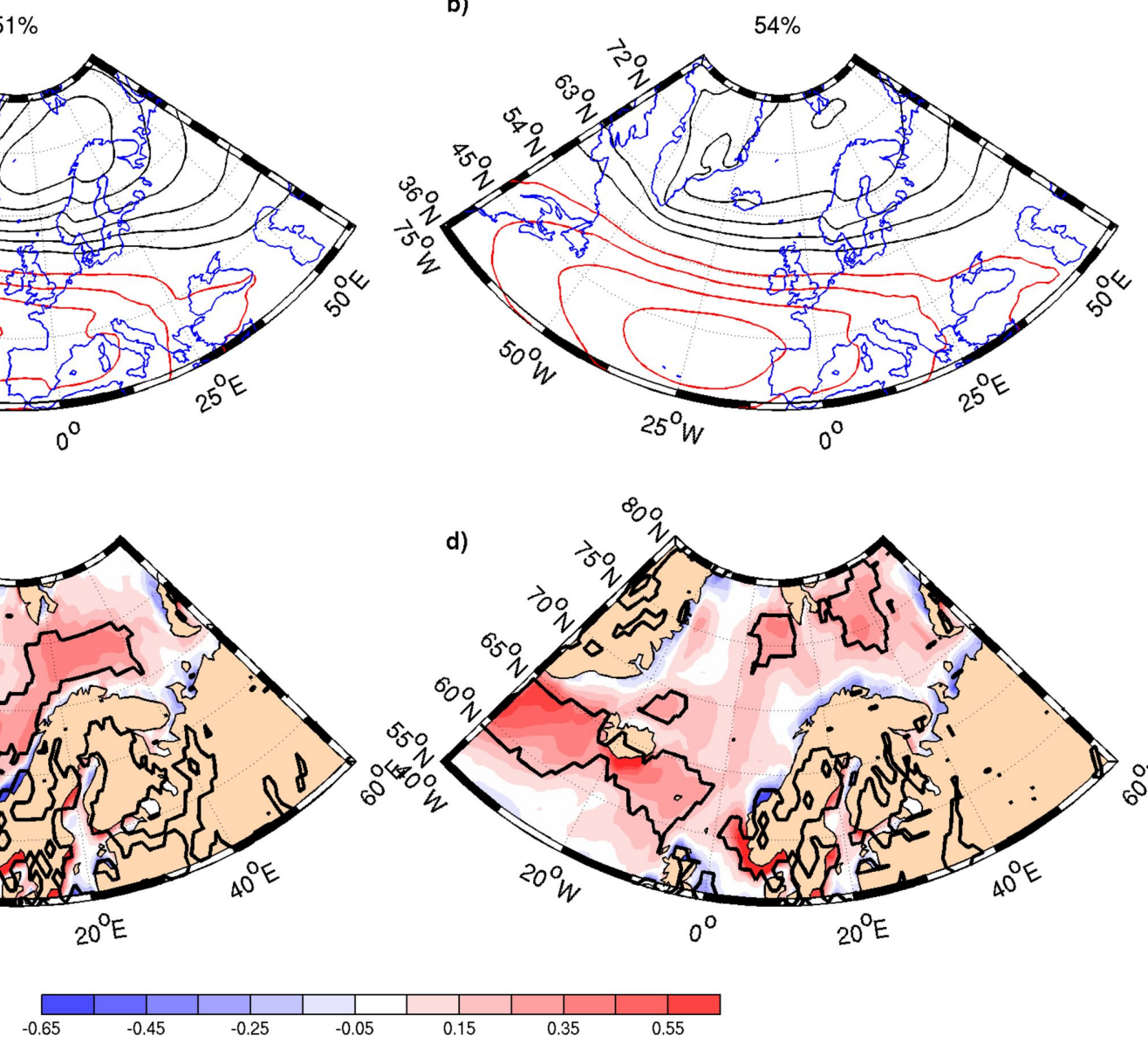
Figure 12.
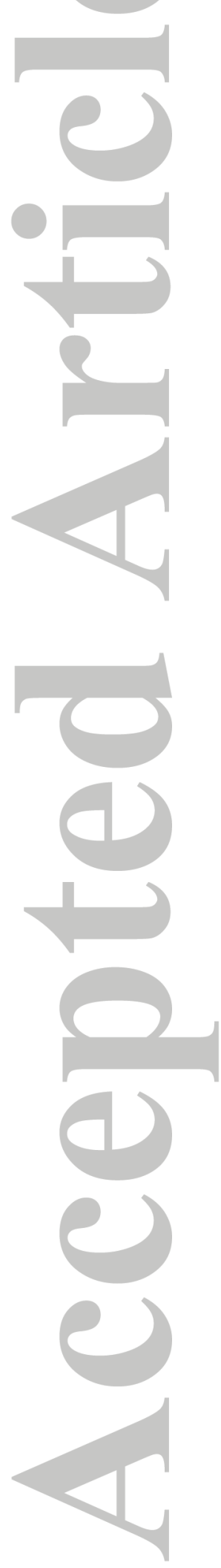

This article is protected by copyright. All rights reserved. 


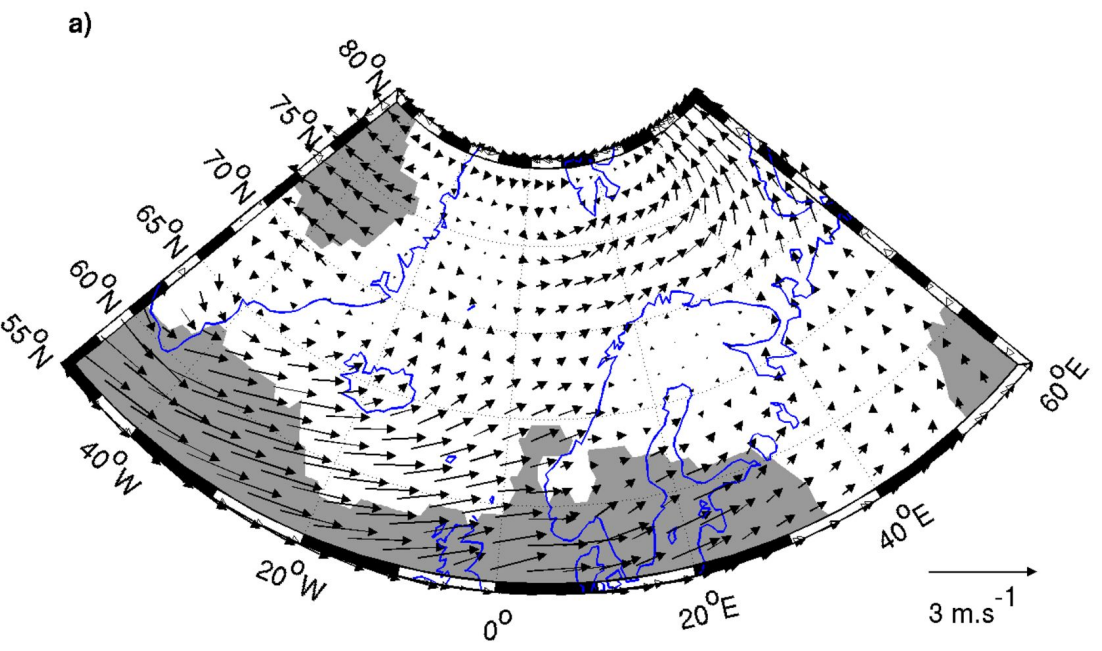

b)

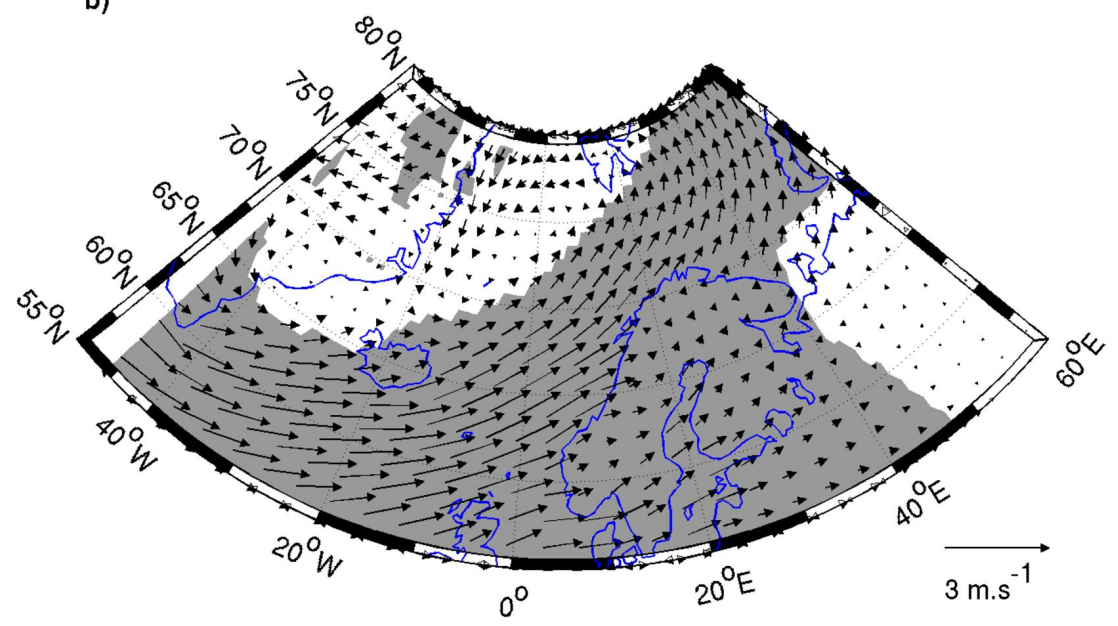


Figure 13.
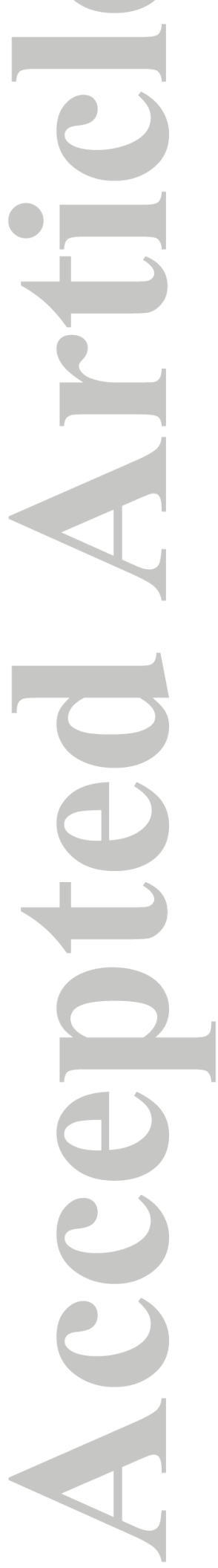

This article is protected by copyright. All rights reserved. 

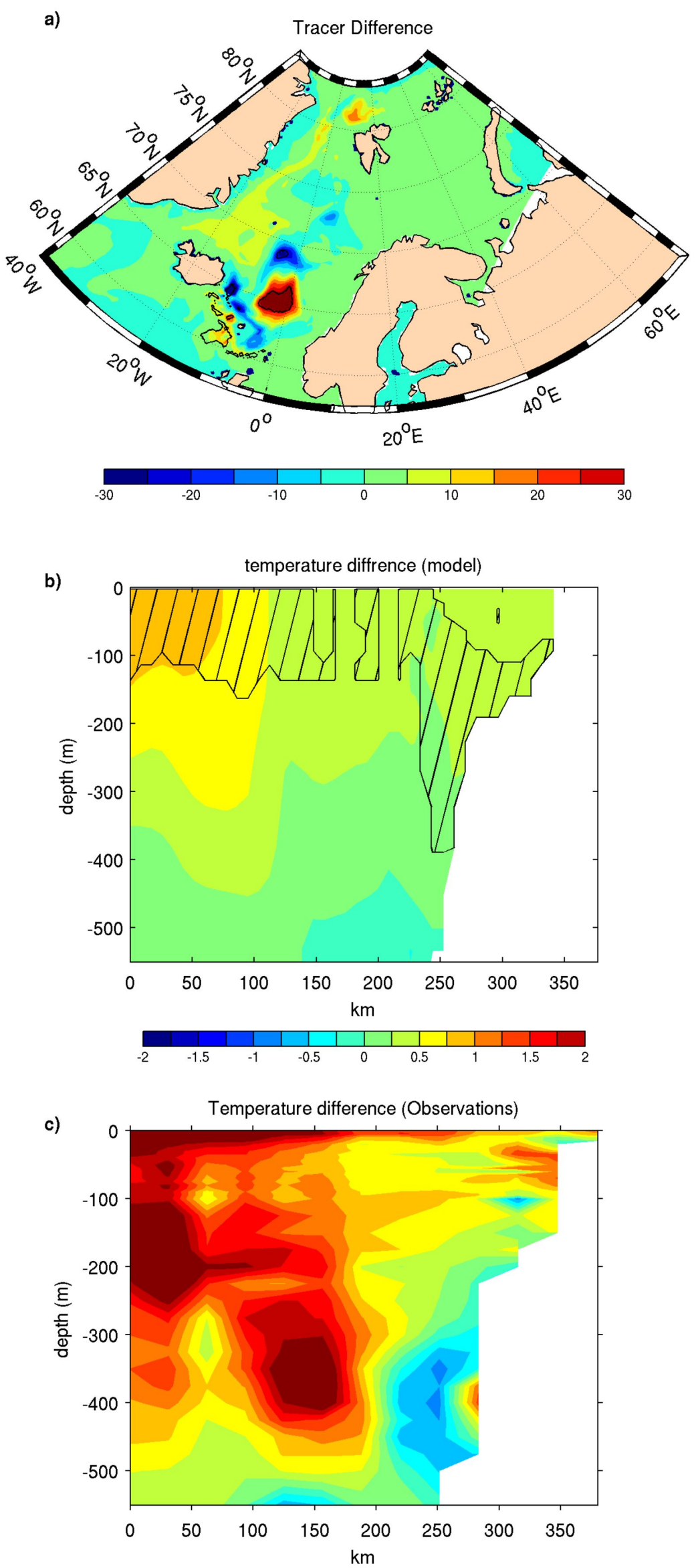

This article is protected by copyright. All rights reserved. 